\title{
Comparing the Incomparable: Towards a Structural Model for FCC Comparative Broadcast License Renewal Hearings
}

The Federal Communications Commission is charged by the Federal Communications Act with allocating use of the public airwaves by dispensing renewable broadcast licenses for particular frequencies on the basis of the "public convenience, interest or necessity." Although the FCC's task ${ }^{3}$ is much more difficult whenever two or more applicants apply for the use of the same or interfering frequencies, the Commission has over the years at least been able to set standards for choosing among original applicants through the procedure known as the comparative broadcast hearing. ${ }^{4}$ Where, on the other hand, one of the applicants is a current incumbent applying for renewal of its license and a so-called comparative renewal hearing is held, the FCC's record has been poorer: ${ }^{5}$ it did not issue a policy statement regarding comparative renewal hearings until $1970,{ }^{6}$ and this policy was vacated by the D.C. Court of Appeals. ${ }^{7}$

147 U.S.C. $\$ \$ 301-98(1970)$.

247 U.S.C. $\$ 307$ (a) (1970). The initial license grant, and subsequent renewals, may not exceed three years in duration. 47 U.S.C. $\$ 307(d)$ (1970).

"The terms "FCC" and "Commission" will be used interchangeably.

'See text and notes at notes $22-60$ infra.

- The comparative renewal hearing has been the subject of considerable controversy in recent years. See, e.g., Geller, The Comparative Renewal Process in Television: Problems and Suggested Solutions, 61 VA. I. Rev. 471 (1975); Goldin, "Spare the Golden Goose"-The Aftermath of WHDH in FCC License Renewal Policy, 83 Harv. L. Rev. 1014, (1970); Hyde, FCC Policy and Procedures Relating to Hearings on Broadcast Applications in Which a New Applicant Seeks to Displace a Licensee Seeking Renewal, 1975 DukE L.J. 253 [hereinafter cited as Hyde]; Jaffe, WHDH: The FCC and Broadcasting License Renewals, 82 HaRv. L. Rex. 1693 (1969); Comment, Media Reform Through Comparative License Renewal Procedures-The Citizens Case, 57 Iowa I. Rev. 912 (1972); Comment, The FCC and Broadcasting license Reneu'als: Perspectives on WHDH, 36 U. ChI. L. Rev. 854 (1969) [hereinafter cited as Curacio Commant; Comment, The Aftermath of WHDH: Regulation by Competition or Protection of Mediocrity? 118 U. PA. I. Rev. 368 (1970).

- Policy Statement Concerning Comparative Hearings Involving Regular Renewal Applicants, 22 F.C.C. 2d 424, 18 P \& F RADro REg. 2D 1901 (1970) [hereinafter cited as 1970 Policy Statement].

' Citizens Communication Center v. FCC, 447 F.2d 1201 (1971). The Federal Communications Act provides for direct appeal to the District of Columbia Circuit from most decisions and orders of the FCC. 47 U.S.C. $\$ 402$ (b) (1970). As virtually all judicial review of FCC action is by the District of Columbia Circuit, the term "Court of Appeals" refers to that court whenever used in the text unless otherwise noted. 
The Commission has been plagued by an inability to reconcile the statutory command that a licensee acquires no vested interest by virtue of initially having been granted a license ${ }^{8}$ with its perception that it is unfair to compel a licensee to forfeit its investment by denying renewal in favor of another applicant. ${ }^{9}$

This comment critically examines the comparative renewal hearing as a mechanism for rational license allocation. After detailing certain procedural requirements common to all comparative hearings, the comment traces the development of the criteria currently applied in ordinary comparative broadcast hearings and demonstrates how they have evolved from a means for predicting the performance of individual licensees to a mechanism for implementing policies regarding the structure of the broadcast industry. The comment then examines how the Commission's reluctance to apply these structural policies to incumbent licensees has led it to disregard its own comparative criteria in comparative renewal hearings and to follow the policy that the Court of Appeals found objectionable. The comment concludes that the comparative renewal hearing as it is currently administered is inherently incapable of choosing between incumbent licensees and challengers. Finally, the comment proposes a procedure designed to enable the Commission to make selections between incumbents and challengers on the basis of objective policies and demonstrates that such a procedure could avoid the objections that led the court to invalidate the Commission's previous approach.

\section{The Development of the Comparative Hearing}

A. The Requirement of a Comparative Broadcast Hearing

The Communications Act requires the Commission to grant applications for licenses for up to three years whenever the "public convenience, interest or necessity will be served thereby,"10 but prohibits the Commission from denying a license ${ }^{11}$ or renewal ${ }^{12}$ application without allowing the applicant a hearing. The Act does not, however, specify procedures for consideration of mutually exclusive applications-contemporaneous applications for stations that

× 47 U.S.C. $\$ \S 301,304,307$ (d), 309(h) (1970).

- See. e.g., Wabash Valley Broadcasting Corp. (WTHI-TV), 35 F.C.C. 677, 1 P \& F Radio Re(i. 2n 573 (1963); Hearst Radio, Inc. (WBAL), 15 F.C.C. 1149, 6 P \& F Radio Reg. 994, aff'd on reconsideration, 16 F.C.C. 141, 6 P \& F Radio REG. 1036d (1951).

I" 47 U.S.C. $\$ 307$ (a) (1970). See also 47 U.S.C. $\$ 309$ (a) (1970).

147 U.S.C. $\$ 309(\mathrm{e})(1970)$.

1247 U.S.C. $\$ 307$ (d) (1970). But see text at notes $178-81$ infra. 
would intolerably interfere with each others' signals. In order to ensure that the Commission does not frustrate either applicant's right to a hearing, the courts have read certain requirements into the Act.

In Ashbacker Radio Corp. v. FCC, ${ }^{13}$ the Commission had before it applications for mutually exclusive licenses; it granted one while setting the other for a later hearing. Even though the "loser's" right to a hearing had been preserved in form, the Supreme Court held that the Commission's procedure had effectively frustrated the "loser's" right to a hearing by converting its hearing into a proceeding to revoke the license of the first applicant. The Supreme Court labeled such a hearing "an empty thing." 14 The Commission implemented the Court's mandate to grant all bona fide mutually exclusive applicants an effective hearing before dispensing the license ${ }^{15}$ by providing for a consolidated comparative broadcast hearing.

The heart of the comparative hearing is the "standard comparative issue"-the determination of which of the basically qualified applicants, if any, will best serve the public interest, convenience and necessity.$^{16}$ Since the comparative hearing is not expressly provided for in the Act, the Commission would seem to be free to develop its own standards for the hearing. Although this is largely true, in Johnston Broadcasting Co. v. FCC, ${ }^{17}$ the Court of Appeals held that the Commission could not "make findings in respect to selected characteristics only," but had to base its decision on a consideration of all of the relevant differences between the applicants. ${ }^{18}$ The Johnston court did not, however, attempt to specify all relevant factors, but left that determination to the Commission.

Despite the teaching of Ashbacker, the Commission does not always grant a hearing before denying an application. The leading case upholding the authority of the Commission to deny applications without hearing is United States $v$. Storer Broadcasting Co., ${ }^{19}$ where an applicant who held more media interests than permitted

326 U.S. 327 (1945).

"Id. at $330-31$.

15 Id. at 333 .

Is Other issues, which are noncomparative, such as the basic qualifications of the applicants, may also be considered in the comparative hearing. See text at notes 131-44 infra.

175 F.2d 351 (D.C. Cir. 1949).

"Id. at 357 . The FCC implements this mandate by granting applicants "preferences" and "demerits" of varying weights according to their showing in comparison with all other applicants on each comparative criterion, and then making the final decision on the basis of the applicants' overall records of preferences and demerits.

1) 351 U.S. 192 (1956). 
by the Commission's multiple ownership rules was denied a license without a hearing. Storer has been followed in a number of cases where applicants had failed to satisfy the Commission's reasonable qualification standards: ${ }^{20}$ the courts have correctly reasoned that little would be served-despite the statutory command-by requiring the Commission to provide a hearing to an applicant whose application is demonstrably inadequate.

Ashbacker, Johnston and Storer therefore establish principles of major importance. The FCC is basically free to determine what factors it will rely on in deciding between mutually exclusive applicants. But once this decision has been made, the Commission must allow all qualified applicants to participate in a comparative hearing to determine which is the best applicant on a consideration of all the relevant factors. These principles apply whether or not one of the applicants is an incumbent. ${ }^{21}$

\section{B. Factors Used in Determining the Comparative Issue}

Since 1965, the Commission has followed its Policy Statement on Comparative Broadcast Hearings ${ }^{22}$ (1965 Policy Statement) in resolving the standard comparative issue. ${ }^{23}$ The inquiry in most cases is limited to consideration of certain characteristics of the applicants, or, in the case of corporate applicants, their principle owners, rather than the details of their proposed station operation. The most important considerations are the number of other media interests owned by the applicants ${ }^{24}$ (diversification) and a combination of their residence and involvement in civic affairs in the community to be served, their proposed degree of full-time participation in station management, and their experience in broadcasting

2" See cases cited at notes 135-36 infra.

21 Although neither of the applicants in Ashbacker was an incumbent, the Court's reasoning applies where one is incumbent, the Court expressly noting that licensees acquire no vested interest in their frequencies. 326 U.S. at 331 n.6; cf. Citizens Communication Center v. FCC, 447 F.2d 1201, 1211 n.31, 1212 n.32 (D.C. Cir. 1971).

${ }^{22} 1$ F.C.C.2d 393, 5 P \& F Radio Reg. 2d 1901 (1965) thereinafter cited as 1965 Policy Statement].

23 The description of the comparative hearing procedure given here is necessarily skeletal. For an exhaustive description and critical analysis, see Anthony, Towards Simplicity and Rationality in Comparative Broadcast Licensing Proceedings, 24 Stan. L. Rev. 1, 26-60 (1971) |hereinafter cited as Anthonyl. For the procedural rules governing the conduct of hearings, see 47 C.F.R. $\$ \$ 1.201-.427$ (1973).

21 "Diversification of control of the media of mass communications" is considered a factor of "primary significance." 1965 Policy Statement, supra note 22, at 394-95, 5 P \& F Rajlo Rea. 2n at 1908. See text at notes 46-57 infra. 
(integration).$^{25}$ Evidence is not taken on proposed programming differences unless one of the applicants requests that the hearing be expanded to include that issue and can show that a significant difference exists. ${ }^{26}$

The emphasis of the 1965 Policy Statement, which is presently being applied to participants in comparative renewal hearings even though by its terms it is not applicable to them, ${ }^{27}$ is quite significant. Even though the Supreme Court has sustained the power of the Commission to base license allocations on the content of the applicant's proposed programming, ${ }^{28}$ the Commission has apparently abandoned any intent to do so directly in the context of original license grants. ${ }^{29}$ The Commission's reluctance to regulate program content probably stems in part from a perception that determining what programming is in the best interest of the public is not only an exceptionally difficult task, ${ }^{30}$ but one that would invariably trench on first amendment values. More important, the Commission's various attempts to predict a licensee's content in the past have all been failures.

The Commission's first attempt to base licensing decisions on proposed programming, expressed in the 1954 Tampa Tribune

25 Local residence and broadcasting experience on the part of applicants' owners who are "integrated" into station management on a full-time basis make up a favorable showing on this criterion. 1965 Policy Statement, supra note 22, at 395-96, 5 P \& F RAdro REc. 2D at 190911. See text at notes $42-43,58-62$ infra.

${ }^{26}$ Id. at 397-98, 5 P \& F Ranio Reg. 2D at 1911-12. Other criteria include past broadcasting record of an owner of an interest in the applicant, which is relevant only if unusually good or poor, id. at 398, 5 P \& F Radio Rec. 2n at 1912-13, and character, which is only set for hearing if a substantial question is raised. Id. at 399, 5 P \& F RAdio REc. 2D at 1913. Other issues may be added on a showing that the evidence will be of substantial value. Id. at 399400, P \& F Radio RFi. 2D at 1913.

"I Id. at 393 n.1, 5 P \& F Radio Rf.,. 2D at 1907 n.I.

N National Broadcasting Co. v. United States, 319 U.S. 190, 217 (1943); see Henry v. FCC, 302 F.2d 191, 193 (D.C. Cir.), cert. denied, 371 U.S. 821 (1962); Johnston Broadcasting Co. v. FCC, 175 F.2d 351, 357 (D.C. Cir. 1949).

29 The Commission does exercise authority over the programming content of existing stations most notably in implementing the "fairness doctrine" which, although it now rests on an explicit statutory mandate, 47 U.S.C. $\$ 315$ (1974 Supp.), was largely developed on the basis of the FCC's general regulatory authority over broadcasters. The constitutionality of FCC regulation of program content seems to have been settled by the Supreme Court in Red Lion Broadcasting Co. v. FCC, 395 U.S. 367, 386-92 (1969); cf. Banzhaf v. FCC, 405 F.2d 1082, 1093-96 (D.C. Cir. 1968), cert. denied, 396 U.S. 842 (1969). But see Bazelon, FCC Regulation of the Telecommunications Press, 1975 Duke L.J. 213, 218-37; Coase, The Federal Communications Commission, 2 .J. LuW \& Econ. 1, 7-12 (1959).

In Cf. H. Friendiy. The Federal, Administrative Agencies: The Neen for Better Standahds 54-57 (1962) [hereinafter cited as Frifndi.y]. 
case, ${ }^{31}$ was a limited one: $:^{32}$ it defined broad categories of programming, such as "public affairs" and "local interest," and, leaving programming details to the discretion of the individual licensee, it placed heavy decisional significance on the percentage of broadcast time applicants proposed to devote to approved program categories. ${ }^{33}$ Reassured by the Commission's reluctance to deny renewal to its licensees, ${ }^{34}$ even to those which failed to live up to their programming promises, ${ }^{35}$ comparative hearing applicants sought to acquire licenses by inflating their public interest programming proposals. ${ }^{36}$

In a 1960 report, ${ }^{37}$ the Commission reviewed the problems inherent in government program regulation and concluded that "the principle ingredient of the licensee's obligation . . . is the diligent, positive, and continuing effort by the licensee to discover and fulfill the tastes, needs, and desires of his community or service area, for broadcast service." ${ }^{38}$ In order to enforce this obligation, the Commission announced that it would no longer set down uniform standards for "approved" programming but would henceforth require all applicants and licensees to base their programming on "the ascertainment of community needs," determined by canvasses of their area and continuing consultation with community leaders. ${ }^{39}$ The

"The Tribune Co., 19 F.C.C. 100, 9 P \& F Rado REg. 719, aff'd on reconsideration, 19 F.C.C. 650 (1954).

${ }^{32}$ See Report and Statement of Policy Res: Commission en banc Programing Inquiry, 44 F.C.C. 2303, 2306 (1960); Broadcasting in America and the FCC's License Renewal Process: An Oklahoma Case Study, 14 F.C.C.2d 1, 10 (1968) (statement by Cox \& Johnson, Comm'rs); Note, Regulation of Program Content by the FCC, 77 HARv. L. REv. 701, 704-06 (1964); Chicaco Comment, supra note 5, at 856-57.

s3 See The Tribune Co., 19 F.C.C. 100, 9 P \& F Radio REg. 719, aff'd on reconsideration, 19 F.C.C. 650 (1954). See also Tampa Times Co., 19 F.C.C. 650,10 P \& F Radio REg. 77 (1954).

31 See note 66 infra.

*5 In a sample of 35 comparative hearing cases between 1952 and 1965, the winners proposed that an average of 31.5 percent of their broadcast time be dedicated to local live broadcasting. Their renewal applications revealed that they delivered an average of 11.8 percent. Moline Television Corp., 31 F.C.C.2d 263, 272, 22 P \& F RADIo REg. 2D 745, 756 (1971). The FCC was understandably reluctant to disinherit an entire generation of licensees. See also KORD, Inc., 31 F.C.C. 85, 21 P \& F Radio REg. 781 (1961).

${ }^{36}$ See Moline Television Corp., 31 F.C.C.2d 263, 272-73, 22 P \& F Radio REG. 2D 745, 756-57 (1971); Geller, A Modest Proposal for Modest Reform of the Federal Communications Commission, 63 Gro. L.J. 705, 716 (1975); Jaffe, WHDH: The FCC and Broadcasting License Reneurals, 82 Harv. I. Rev. 1693, 1695 (1969); Schwartz, Comparative Television and the Chancellor's Foot, 47 Gro. IJ.J. 655, 659-60 (1959) [hereinafter cited as Schwartz].

"Report and Statement of Policy Res: Commission en banc Programing Inquiry, 44 F.C.C. 2303 (1960).

${ }^{3 \times}$ Id. at 2316.

s. Id. 
following year, in Suburban Broadcasters, Inc., ${ }^{40}$ the Commission applied this principle to deny the application of an unchallenged applicant which had submitted identical proposals for stations in three widely varying service areas without making satisfactory efforts to ascertain the needs of the communities it proposed to serve.

The Suburban approach was clearly a major step by the Commission in the direction of not exerting direct control over the ultimate product of the broadcast industry, programming. Where the Commission had previously limited itself to assuring that licensees would promise to air some form of public-interest programming, in the Suburban case it further limited its role to ensuring that licensees would employ decision-making processes that would presumptively result in quality programming responsive to community needs. Nevertheless, deciding comparative hearings on the basis of the community ascertainment approach retained the basic flaw of the earlier approach by relying on the promises of the applicants. ${ }^{41}$ Given its inability or unwillingness to scrutinize renewal applications effectively, the Commission could not monitor an applicant's continuing efforts to ascertain community needs once it had been granted a license.

In the 1965 Policy Statement, the Commission took the final logical step away from attempting to distribute operating licenses on the basis of proposed programming content by turning to an examination of the programmers themselves. First, the primary issues under the pre-1965 procedures-programming proposals, community needs ascertainment and service philosophy-were combined into the single criterion of "proposed program service"; this consolidated issue is only to be set for hearing if one of the applicants demonstrates the existence of a substantial and material dif-

to 30 F.C.C. 1021, 20 P \& F Radio Reg. 951, aff'd sub nom. Henry v. FCC, 302 F.2d 191 (D.C. Cir. 1961), cert. denied, 371 U.S. 821 (1962).

"The community needs ascertainment issue was developed in the context of setting minimum qualifications for all applicants rather than deciding between applicants in a comparative hearing. Although the needs ascertainment issue could be applied in comparative hearings, see, e.g., Burlington Broadcast Co., 34 F.C.C. 1135, 25 P \& F Rado RF.. 633 (1963), and received judicial approval as a comparative factor, Great Lakes Broadcasting Co. v. FCC, 289 F.2d 754 (D.C. Cir. 1960), it did not appear to have much impact on comparative hearings. Its real significance was that by focusing the Commission's concern for selecting licensees who would present public-interest programming on applicants' ascertainment mechanisms at the basic qualification level, it paved the way for the complete abandonment of the predictive approach to comparative decisions in the 1965 Policy Statement. See text at notes 60-62 infra; cf. Note, Judicial Review of FCC Program Diversity Regulations, 75 Col.l'M. I.. Rev. 401, 403-05 (1975). 
ference. ${ }^{42}$ Second, the Commission elevated to decisional prominence certain criteria-namely diversification and integration-that had been developing over the years but had previously been used primarily as circumstantial evidence of the likelihood of an applicant implementing its proposals. ${ }^{43}$

Under the 1965 Policy Statement, license allocations are to be made on the basis of two primary policy goals, the "maximum diffusion of control of the media of mass communications" (diversification) ${ }^{4}$ and "the best practicable service to the public," which, although it includes several other issues, is dominated by "full time participation in station management by owners," or the integration issue. ${ }^{45}$ Integration in turn embraces the subordinate issues of licensee experience and local residence. This elevation to decisional significance of what previously had been merely evidentiary factors represented more than the Commission's recognition that it could not trust applicants' representations; it represented a change in the philosophy of license allocations away from predictions of programming content and toward structural policies.

Since the inception of the comparative hearing procedure, the Commission has considered the number of other media interests held by applicants in a comparative hearing to be a relevant decisional factor ${ }^{46}$ for two reasons: first, the Commission presumed that an applicant with no other media interests would be willing to devote more attention to the facility in question; ${ }^{47}$ second, in keeping

121965 Policy Statement, supra note 22, at 397-98, 5 P \& F Radio REG. 2D at 1911-12. An applicant's record in operating other facilities can only be considered if unusually good or poor. Id. at 399, 5 P \& F Rabio Rec. 2D at 1912.

13 Being merely evidentiary factors going to the reliability of predictions, these criteria in pre-1965 hearings could be overridden by more persuasive evidence of an applicant's reliability-most commonly the applicant's record in operating another station. See WJR, The Goodwill Station, 21 F.C.C. 972, 14 P \& F Radro REg. 905 (1956); The Tribune Co., 19 F.C.C. $100,151-52,9$ P \& F Ranio RF.s. $719,770 \mathrm{~b}-\mathrm{c}$, aff'd on reconsideration, 19 F.C.C. 650 , 651-52 (1954). In the latter case, the loser argued that by so disregarding its own criteria the Commission acted arbitrarily, but this argument was rejected by the Court of Appeals. Pinellas Broadcasting Co. v. FCC, 230 F.2d 204, 205-06 (D.C. Cir.), cert. denied, 350 U.S. 1007 (1956).

"1965 Policy Statement, supra note 22, at 394, 5 P \& F Radio REc. 2D at 1908.

"1 F.C.C.2d at 395-96, 5 P \& F Ranio Reg. 2n at 1909-10. In accordance with the elevation of these predictive factors to decisional significance, the separate issue of likelihood of effectuation of proposals was dropped. Id. at 398, 5 P \& F RADio REG. 2D at 1912.

13 Bamberger Broadcasting Serv., 11 F.C.C. 211, 222, 3 P \& F RADIo REG. 914, 925 (1946).

17 The number of other media interests held by an applicant was relevant to the local ownership issue. See Irion, FCC Criteria for Evaluating Competing Applicants, 43 Minn. L. Rww. 479, 483 (1959) [hereinafter cited as Irion]; Schwartz, supra note 36, at 661-62. For a modern application of this principle, see Nelson Broadcasting Co., 3 F.C.C.2d 84, 7 P \& F 
with first amendment notions that democratic government requires free access to the marketplace of ideas, a policy that maximized the number and diversity of broadcast licensees was considered desirable per se. ${ }^{48}$

In 1954 , the Commission took a significant step towards viewing diversification as an independent policy ground for license allocations. In McClatchy Broadcasting Co. ${ }^{49}$ the Hearing Examiner had found one applicant slightly superior on all criteria except diversification, on which it was clearly inferior. Finding that this applicant had given its other stations freedom to express their own opinions, the Examiner concluded that diversification was not a relevant factor and awarded the applicant the license. ${ }^{50}$ The Commission reversed, holding that diversification was desirable in and of itself; ;1 the Court of Appeals affirmed.52 Encouraged by the Court of Appeals under the influence of Judge Bazelon, ${ }^{53}$ the Commission continued to move towards establishing diversification as an independent ground for license allocation. ${ }^{54}$ The Commission's adoption of its first so-called multiple-ownership rules, placing a limit on the number of licenses that could be held by an individual licensee, ${ }^{55}$ which were approved by the Supreme Court, ${ }^{56}$ hastened this process.

In the 1965 Policy Statement, the Commission finally elevated diversification to the status of a policy goal equal to "best practicable service." In keeping with the McClatchy Broadcasting approach, diversification represents a structural policy rather than a manner of predicting service. The Commission, in setting guidelines regarding diversification, indicated no concern with whether a multiple-licensee applicant had in fact allowed its other stations programming autonomy. The factors it will consider are the size of the applicant's other media interests and the proximity of these

\footnotetext{
Rabio Rfc. 2n 146 (Rev. Bd. 1966).

ix The Commission's development of this theory in the 1950's is summarized and criticized in FriFnd.Y, supra note 30, at 63-70.

s 19 F.C.C. 343, 9 P \& F Radio Res. 1190 (1954).

so The Examiner's report is summarized and reprinted in part in McClatchy Broadcasting Co. v. FCC, 239 F.2d 15, 16 \& n.2 (1956).

s19 F.C.C. at 379-81, 9 P \& F Radio Reci. at 1220i-j.

52 McClatchy Broadcasting Co. v. FCC, 239 F.2d 15 (D.C. Cir. 1956). See also ScrippsHoward Broadcasting Co. v. FCC, 189 F.2d 677 (D.C. Cir. 1951).

${ }_{33}$ See Hyde, supra note 5, at 261.

s: See Young People's Church of the Air, Inc., 28 F.C.C. 617, 623-24, 18 P \& F Radro REg. 947. 948g-h (1960) (R. Lee, Comm'r, dissenting), vacated, 36 F.C.C. 1127, 2 P \& F Radio Rfo. 2) 527 (1964).

$\approx 47$ C.F.R. $\$ \S 3.35,3.240,3.636$ (1958).

56 United States v. Storer Broadcasting Co., 351 U.S. 192 (1956).
} 
interests to the broadcast area in question. ${ }^{57}$

The structural rationale underlying the 1965 Policy Statement's treatment of integration is, upon examination, parallel to that of diversification. Here again the Commission early on developed a structural policy favoring locally owned and operated stations per se, regardless of their proposed programming, which it could call upon in close cases. ${ }^{58}$ Similarly, the Commission's preoccupation with predictions of service quality ${ }^{59}$ obscured the policy's significance and weakened its force in comparative hearings ${ }^{60}$ before its elevation to prominence in the 1965 Policy Statement.

The significance of the 1965 Policy Statement is twofold: it represents the end to the FCC's attempts to determine which competing applicant would provide better programming and it signals the beginning of an attempt to base licensing decisions on a comparison of certain structural qualities of the applicants. In 1965, the Commission constructed a model of the type of licensee which it felt was most likely to program its station in accordance with the public interest, relying on evidentiary factors which it had previously used in estimating whether an applicant was likely to carry out its promises. Because of its inability to determine which licensee would provide the better programming performance other than through this model, however, the Commission has established a virtually irrebuttable presumption that the applicant which most closely conforms to that model of diversity and integration will best serve the public interest. ${ }^{61}$ This approach makes sense in the cases for which it was designed-cases where none of the applicants are current incumbents-because it avoids the problems of predicting which applicants will provide the best service and bases allocational decisions on policy grounds capable of fairly objective determination. ${ }^{62}$

sī 1965 Policy Statement, supra note 22, at 394-95, 5 P \& F Radio REg. 2D at 1908-09. Sce Fidelity Television, Inc. v. FCC, 515 F.2d 684, 715 \& n.40 (D.C. Cir. 1975), cert. denied, 44 U.S.L.W. 3263 (U.S. Nov. 4, 1975).

:N See Irion, supra note 47 , at 483.

ss The three factors which make up the modern integration test-full-time participation in station management, local residence, and experience-were clearly considered primarily as evidentiary factors long after diversification had been recognized as an independent structural policy. Irion, supra note 47 , at $483-88$.

so See Judge Friendly's critique of the Commission's misapplication of the local interest policy. Friteniti, supra note 30 , at 58-63.

61 As of August, 1971, the Commission had not awarded a single preference for proposed programming in a comparative hearing since the 1965 Policy Statement went into effect. Moline Television Corp., 31 F.C.C.2d 263, 273, 22 P \& F Radio REg. 2d 745, 757 (1971).

62 It should be recognized, however, that the Commission's method of adopting a structural policy rationale for license allocations without explicitly saying what it was doing or 
However, this late adoption of a policy favoring integrated, diversified stations in an industry largely composed of corporations with precisely the opposite qualities raised new questions about the Commission's standards in license renewal challenges.

\section{The Comparative Renewal Hearing}

The standard comparative issue-now constituted primarily of the diversification and integration criteria-was developed to enable the Commission to make licensing decisions in cases where none of the applicants are incumbents and thus there is no station in operation on the frequency in question. When, on the other hand, one of the candidates in a comparative hearing is seeking to renew an operating license, some service is being rendered which will be discontinued if the challenge is successful; different issues therefore logically arise. Not surprisingly, the comparative renewal hearing has developed along different lines than the standard comparative hearing involving nonincumbents.

\section{A. Comparative Renewal Standards Prior to 1965}

Prior to 1965, the Commission decided only two comparative

opening up the subject for comment through rulemaking is open to criticism. Indeed, the Commission has never acknowledged the real basis for the integration criterion as applied since 1965; some respectable opinion regards the 1965 Policy Statement as nothing more than the Commission's retreat into reliance on formalistic criteria with no real connection to the prediction of licensee performance, in order to avoid the problems of probing the sincerity of applicants. Hyde, supra note 5, at 268-77. If, however, the Commission would acknowledge the structural basis of its present allocation policies and reexamine them through rulemaking, such policies would seem to be preferable to the discredited process of predicting performance. Able observers of the comparative hearing process have criticized the Commission for failing to develop more objective policy grounds for allocating licenses. Where no such objective decision is possible, the critics suggest using a lottery, competitive bidding, or some similar mechanism to make the final decision without the necessity of engaging in predictions of licensee performance. Star Television, Inc. v. FCC, 416 F.2d 1086, 1094-95 (D.C. Cir. 1969) (Leventhal, J., dissenting); FrIEndLY, supra note 30, at 70-71; Anthony, supra note 3, at 66-72. The relegation of the issue of predicting licensee performance to the level of basic qualifications, via the Suburban issue, makes this approach a possibility. See text at notes 40-41 supra. But see text and notes at notes $155-56$ infra.

The FCC has maintained that rulemaking is inappropriate in the formulation of standards for comparative hearings, arguing that application of its various interrelated criteria is most appropriately an adjudicative task. See Petitions for Rulemaking, in re Policy Statement Concerning Comparative Hearings Involving Regular Renewal Applicants, 24 F.C.C.2d 383 (1970) (reconsideration denied); cf. Brief for Respondents at 40-42, Citizens Communication Center v. FCC, 447 F.2d 1201 (D.C. Cir. 1971). But see the Commission's attitude on frequency allocation, note 137 infra, and K. Davis, Administrative Law Treatise. $\S 6.14$ (1970 Supp.) 
renewal cases, ${ }^{63}$ in each renewing the license of the incumbent. Following the so-called Hearst doctrine, after the decision in Hearst Radio, Inc. ${ }^{64}$ the Commission declared that the challenger was under a heavier burden of persuasion than an incumbent in an ordinary comparative hearing. ${ }^{65}$ This position was logical when the basis for license allocation was prediction of program quality. An incumbent's record of past performance is clearly the best indicator of its future performance, and in light of the uncertainty of predicting performance by untried applicants under the Tampa Tribune approach, it was inevitable that challengers would face an almost insuperable burden of persuasion. ${ }^{66}$

The change in allocation bases signalled by the 1965 Policy Statement raised entirely new issues. Incumbents in comparative renewal hearings have no inherent advantages under the Statement's structural system as they have under a predictive sys-

${ }^{63}$ Wabash Valley Broadcasting Corp. (WTHI-TV), 35 F.C.C. 677, 1 P \& F RADIo REg. 2n 573 (1963); Hearst Radio, Inc., 15 F.C.C. 1149, 6 P \& F Radio Reg. 994, aff'd on reconsideration, 16 F.C.C. 141, 6 P \& F RADIo REc. 1036d (1951). A handful of other cases have involved comparative hearings in which one applicant was seeking renewal of a fourmonth temporary license which the Commission had granted specifically to encourage other applicants. See Community Broadcasting Corp. v. FCC, 363 F.2d 717 (D.C. Cir. 1966); South Fla. Television Corp. v. FCC, 349 F.2d 971 (D.C. Cir. 1965).

6t 15 F.C.C. 1149, 6 P \& F Radio Rf.. 994, aff'd on reconsideration, 16 F.C.C. 141, 6 P \& F Rabio Rrs. 1036d (1951).

is See note 43 supra. The first comparative renewal case, Hearst, was contemporaneous with Tampa Tribune and WJR and, like them, is based heavily on the superior basis for prediction of future service found in the examination of an applicant's record of operation. 15 F.C.C. at 1175-76, 6 P \& F Ranio RFr. at 1026-27. In Wabash Valley, the FCC relied on the Hearst precedent to reject the challenger's argument that consideration should be limited to the records of the AM stations owned by both applicants, since each had a record to be compared on. Declaring the incumbent's record on the frequency in question to be "the most reliable gage as to what can be expected . . . in the future", the Commission then discounted the challenger's "commendable" record as an AM operator because it was "compiled in a different medium and city than the ones here involved . . . "35 F.C.C. at 678-79, 1 P \& F Raimo Rr(i. 2n at 576-77.

${ }_{6 \mathrm{~B}}$ The Commission has always been reluctant to deny renewal for any reason and has often been accused of identifying too closely with powerful elements of the broadcast industry. Sce. e.g., Geller, A Modest Proposal for Modest Reform of the Federal Communications Commission, 63 Gro. L.J. 705, 716 (1975). Prior to 1969, only 74 renewal applications were denied. Hearings on S. 2004 Before the Subcomm. on Communications of the Senate Comm. on Commerce, 91st Cong., 1st Sess., pt. 1, at 38 (1969) [hereinafter cited as Hearings]; see Broadcasting in America and the FCC's License Renewal Process: An Oklahoma Case Study, 14 F.C.C.2d 1 (1968) (statement by Cox \& Johnson, Comm'rs); Comment, Media Reform Through Comparative License Renewal Procedures-The Citizens Case, 57 Iowa L. Rev. 912, 918-21 (1972). The Commission's reluctance to deny renewal found support in Court of Appeals decisions stressing the "compelling reasons" needed to divest a broadcaster of its license. Evangelical Lutheran Synod v. FCC, 105 F.2d 793 (D.C. Cir. 1939); Chicago Fed'n of Labor v. Federal Radio Comm'n, 41 F.2d 422 (D.C. Cir. 1930). See also WOKO, Inc. v. FCC, 153 F.2d 623 (D.C. Cir.), rev'd, 329 U.S. 223 (1946). 
tem. Indeed, they are usually at a disadvantage. Most comparative renewal hearings involve an application filed by residents of the service area involved with no other media interests, attempting to displace a pre-1965 licensee owned by a large broadcasting corporation or by some other local media, such as a newspaper. ${ }^{67}$ Yet in order to apply its comparative criteria in such a situation, the Commission must first determine as a matter of policy that the diversification and integration policies should be given retroactive effect; in other words, that the public interest requires restructuring the pre1965 part of the broadcast industry to conform to the Commission's ideal structural model. In noncomparative cases the Commission has been reluctant to give its structural policies such retroactive effect. ${ }^{68}$

In determining whether to restructure the pre-1965 industry, the Commission faces different problems in unopposed renewal hearings and comparative renewal hearings. Refusing renewal to a licensee in a noncomparative situation on the basis of the structural policies would require a judgment that the furthering of those policies is more important than the continued provision of the licensee's

${ }^{57}$ See 40 Gro. Wash. L. Rev. 571, 578-79 (1972); cf. WHDH, Inc., 16 F.C.C.2d 1, 25-26, 15 P \& F Radio Rfa. 2n 411, 435-36 (1969) (R. Lee, Comm'r, dissenting).

Bx Thus, although the Commission has established rules placing an absolute limit on the number of licenses one licensee can hold, in 1970 it decided it would not apply these rules to existing multiple licensees pending further rulemaking directed specifically to the question of divestiture. First Report and Order, in re Amendment of Commission Rules Relating to Multiple Ownership, 22 F.C.C.2d 306, 322-23, 18 P \& F Radio Reg. 2D 1735, 1755-56 (1970); Further Notice of Proposed Rulemaking, in re Amendment of Commission Rules Relating to Multiple Ownership, 22 F.C.C.2d 339 (1970). This required five years to complete, and re. sulted in the Commission declining to order divestiture based solely on the number of licenses held by a single licensee, limiting divestiture to situations where one licensee controls virtually all of the media in a service area. Second Report and Order, in re Amendment of Commission Rules Relating to Multiple Ownership, 50 F.C.C.2d 1046, 32 P \& F Radio Rer. 2n 954 (1975).

This approach is also reflected in several cases, decided before 1975 and affirmed by the Court of Appeals, in which the Commission refused to entertain petitions to deny renewal filed by interested non-applicants under 47 U.S.C. $\$ 309$ (d) (1970). The petitions alleged that the licensees in question had consolidated an undue concentration of media control, but were considered deficient because they failed to allege specific abuses. Columbus Broadcasting Coalition v. FCC, 505 F.2d 320 (D.C. Cir. 1974); Stone v. FCC, 466 F.2d 316 (D.C. Cir. 1972); Hale v. FCC, 425 F.2d 556 (D.C. Cir. 1970).

The Commission has not had occasion to address the restructuring issues involved in the application of the integration criterion to existing stations, as it continues to regard integration as evidentiary of predicted service and hence irrelevant in the uncontested renewal cases. See text at notes 131-33 supra. One commentator, referring primarily to integration, has noted that "Commission concern for the structure of the communications industry has been virtually ignored in the traditional renewal procedure." Chicago Comment, supra note 5, at 868. 
broadcasting services. In the comparative renewal hearing, on the other hand, the question is who will provide broadcasting service, not whether it will be provided. In order to justify not applying the standards of the 1965 Policy Statement in this situation, the Commission would have to assert some policy grounds for preferring incumbents. Although such a policy could perhaps be found where the incumbent has a record of providing exceptional service, unlikely to be matched by the challenging applicant, it is more difficult to justify refusing to apply the structural policies in a comparative renewal hearing where the licensee has an average operating record substantially in accord with prevailing industry norms. In such a case a challenger can be expected to provide service roughly equivalent to that of the incumbent. ${ }^{69}$ Thus by adopting an allocational scheme which did not rely on proposed programming quality and adopting criteria which virtually invited challenge to established industry giants, the Commission paved the way for the current comparative renewal controversy.

\section{B. The WHDH Case and the 1970 Policy Statement}

In 1969 the Commission startled the broadcast industry when, in its first post-1965 comparative renewal case, it appeared to abandon the Hearst doctrine. In WHDH, Inc. ${ }^{70}$ the Commission refused to renew the license of a Boston television station owned by a newspaper that also operated two radio stations, granting the license instead to a challenger with no other media interests. The Commission found that the incumbent's broadcasting record was only average and declared that as a result the incumbent was not entitled to preferential treatment in the hearing. Applying the 1965 Policy Statement standards, even though the Statement was by its own terms limited to non-renewal situations, ${ }^{71}$ the Commission found the challenger to be superior on both diversification and integration grounds and thus deserving of the license. ${ }^{72}$

In response to intense criticism generated by a fear that the Commission's new doctrine would jeopardize established broadcast-

"99 This conclusion is supported by the fact that an applicant qualified under the Suburban test has demonstrated an ability to provide the minimum level of communityoriented programming required of all applicants. See text at note 40 supra.

in WHDH, Inc., 16 F.C.C.2d 1, 15 P \& F RaDio REG. 2D 411 (1969), aff'd sub nom. Greater Boston Television Corp. v. FCC, 444 F.2d 841 (D.C. Cir.), cert. denied, 403 U.S. 923 (1971).

" 1965 Policy Statement, supra note 22, at 393 n.1, 5 P \& F RADio REG. 2D at 1907 n.1.

7216 F.C.C.2d at 7-10, 15 P \& F Radio REG. 2D at 421-24 (1969). 
ers' substantial investments, ${ }^{73}$ the FCC backed away from $W H D H$, subsequently declaring that its decision in that case was sui generis because WHDH had been operating under a four-month temporary license, and hence was not a true incumbent licensee. ${ }^{74}$ This recantation did not appease the critics, however, and in 1970 the Commission, reacting to pending legislation ${ }^{75}$ that would have abolished the comparative renewal proceeding altogether, issued its Policy Statement Concerning Comparative Hearings Involving Regular Renewal Applicants ${ }^{76}$ (1970 Policy Statement).

The 1970 Policy Statement was the Commission's first attempt to set forth explicitly the policies governing comparative renewal hearings. The statement provided that hearings would focus at first solely on the record of the incumbent. Competing applicants could participate, but their participation would be limited to pointing out weaknesses in the incumbent's record. ${ }^{7}$ If found to have been "substantially attuned to meeting the needs and interest of its area"78 throughout the previous license term, the incumbent would be granted renewal without a comparative inquiry; otherwise, all applicants would be compared under the 1965 Policy Statement criteria.

To justify giving incumbents such an advantage, the Commission asserted that the public interest in stability in the-broadcast industry required that those broadcasters who provided substantial service be assured of renewal. In support of this position, the Commission pointed out the difficulty of predicting the calibre of performance of an untried applicant and concluded that the public might not benefit from replacing a competent incumbent with an

${ }^{73}$ The leading article in the attack on WHDH was Jaffe, WHDH: The FCC and Broadcasting License Renewals, 82 HARV. L. REv. 1693 (1969), which characterized the decision as a "desperate and spasmodic lurch toward 'the left' . . . ." Id. at 1700. For the industry's views on WHDH, see Three Billion Dollars in Stations Down the Drain? BroadCasting, Feb. 3,1969 , at 19.

24 WHDH, Inc., 17 F.C.C.2d 856, 16 P \& F RADio REG. 2D 185 (1969) (reconsideration denied). As the station had been operating on a four-month temporary license because of its former president's alleged attempts to improperly influence the Commission chairman, the Commission contended that it was similar to other comparative hearings involving incumbents not considered "true renewal candidates." See cases cited at note 63 supra. The decision was affirmed on this ground. Greater Boston Television Corp. v. FCC, 444, F.2d 841, 853-59 (D.C. Cir.), cert. denied, 403 U.S. 923 (1971). This factor in the case leads to the conclusion that perhaps the furor over WHDH was caused not so much by the decison as by the Commission's broad language in its first opinion. See text at note 72 supra.

${ }^{75}$ See generally Goldin, "Spare the Golden Goose"-The Aftermath of WHDH in FCC License Renewal Policy, 83 HaRv. L. Rev. 1014 (1970).

${ }_{76} 22$ F.C.C.2d 424, 18 P \& F RAdio REg. 2D 1901 (1970).

"Id. at 428, $18 \mathrm{P} \& \mathrm{~F}$ RADIo REG. 2D at 1908.

${ }^{7 x}$ Id. at 425, $18 \mathrm{P} \&$ F RAdIo REG. 2D at 1904-05. 
unknown product. ${ }_{-}^{79}$ The Commission also drew on its courtapproved cautionary approach to applying structural policies retroactively $^{80}$ and stated that stability required that rulemaking proceedings be engaged in before licensees were divested of their licenses on the basis of diversification. ${ }^{81}$

At the same time, the Commission instituted rulemaking proceedings $\mathrm{s}^{\mathrm{2}}$ to define the meaning of "substantial service" for VHF television stations. The Commission indicated that substantial service should be defined in terms of percentages of air time that stations should devote to various categories of public interest programming ${ }^{83}$ industry-wide norms would be established that any ordinary licensee should be able to meet..$^{84}$

If this concept of substantial service is read together with the 1970 Policy Statement, the Commission's composite 1970 position is that the public interest in stability requires that any station which meets the average level of service for the industry be insulated against replacement in a comparative renewal proceeding. To some extent this position reflects the Commission's earlier and unsuccessful attempts to predict programming performance; in this sense it is anachronistic. However, the 1970 Policy Statement also reflects to an extent the Commission's more modern concern with the structure of the industry.

79 Id. at 429, 18 P \& F Radio Reg. 2D at 1909.

ко See note 68 supra.

xI Id. at 427, $18 \mathrm{P} \&$ F Radio Reg. 2D at 1907.

${ }^{82}$ Notice of Inquiry, in re Formulation of Policies Relating to the Broadcast Renewal Candidate, Stemming from the Comparative Hearing Process, 27 F.C.C.2d 580, 53 P \& F Radio Reg. CurRent SERV. 429 (1971). This proceeding apparently has not been concluded. See Third Further Notice of Inquiry, 43 F.C.C.2d 1043, P \& F Radio REg. Current Serv. 442h (1973).

${ }^{* 3}$ The Commission tentatively proposed that all stations devote $10-15$ percent of their broadcast time to local programming, that independent stations devote 5 percent of their time to news and network affiliates 8-10 percent, and that all stations devote 3-5 percent to public affairs programming. Notice of Inquiry, 27 F.C.C.2d 580, 581, 53 P \& F Radio REG. CuRRENT SERV. 429, 431 (1971).

*4 The Commission's approach is to set its substantial service standard within the reach of the average station. See Policy Statement Concerning Comparative Hearings Involving Regular Renewal Applicants, 22 F.C.C.2d 424, 426-27, 18 P \& F RADIo REG. 2D 1901, 1904 (1970); cf. RKO General, Inc., 44 F.C.C.2d 149, 228, 16 P \& F RADIo REG. 2D 1181, 1271 (Hearing Examiner 1969) (initial decision). In fact, the statistics the Commission published with its Third Further Notice of Inquiry indicate that its proposed standards have already been met by the bulk of the industry, 43 F.C.C.2d at 1045-68, 53 P \& F Radio REg. Current SERv. 442j-gg. It may be speculated that this is an example of what has been called "regulation by raised eyebrow," i.e., the mere announcement that the Commission considered the percentages suggested in the Notice of Inquiry "substantial" was enough to bring the industry, solicitous of its licenses, into line. 
The 1970 Policy Statement was an admirable, though misguided, ${ }^{85}$ attempt by the Commission to reconcile the competing structural policies of encouraging stability and promoting a diversified-integrated broadcasting industry. In the typical comparative renewal situation, the Commission is faced with two applicants, one of which would serve the policy of stability, the other the policy of diversity-integration. Since the Commission has found it impossible to predict which applicant will provide better service, there is no common ground on which to compare the two. The Commission must decide, as a matter of policy, which interest is more compelling in such situations-stability or integrationdiversification. The 1970 Policy Statement, for all its flaws, was an attempt to do just that.

\section{The Citizens Case}

The 1970 Policy Statement was short-lived, however. In Citizens Communication Center v. FCC, ${ }^{86}$ the Court of Appeals vacated the Policy Statement in its entirety, before it could be applied in any hearing. ${ }^{87}$ The petitioners, two nonprofit organizations interested in "improving" the media and two parties to pending hearings, ${ }^{88}$ challenged the 1970 Policy Statement on the grounds that it abridged the challenger's statutory right to a hearing as interpreted in the Ashbacker case, ${ }^{89}$ and that it had been promulgated in disregard of the rulemaking procedures of the Administrative Procedure Act. ${ }^{91}$ Without reaching the procedural question, ${ }^{91}$ the court noted that it was quite plain that the truncated hearing procedure of the 1970 Policy Statement, in which a license renewal could be granted without allowing challengers a hearing on the merits of their own

${ }^{85}$ The Commission's definition of stability is criticized in text at notes $146-49$ infra.

st 447 F.2d at 1214.

${ }^{87}$ Like WHDH, Citizens generated the introduction of legislation that would have substantially cut back on, or eliminated entirely, the comparative renewal procedure. For a legislative history, see Hyde, supra note 6, at 254 n.12. See generally FCC License Renewal Reform: Two Comments on Recent Legislative Proposals, 42 Geo. Wash. L. Rev. 67 (1973).

447 F.2d at 1202 n.2.

* See text and notes at notes 13-15 supra.

? 5 U.S.C. $\$ 553(1970)$.

"The court declined to decide Citizens on the basis of the Commission's failure to employ notice-and-comment rulemaking proceedings under $\$ 553$ of the APA, 5 U.S.C. $\$ 553$ (1970), but it termed the Commission's arguments that such a proceeding was unnecessary "remarkable." 447 F.2d 1204 n.5. Nevertheless, the court again refused to order the Commission to engage in rulemaking to determine the meaning of "superior service" when the case came before it again two years later. Citizens Communication Center v. FCC, 463 F.2d 822 (D.C. Cir. 1973). 
applications, was the same sort of proceeding condemned in Ashbacker as an "empty thing." 92

The Citizens case raises difficult problems of interpretation. It could be maintained that Citizens requires only that the Commission give challengers a chance to present the merits of their applications before making a decision, but that the Commission can still apply whatever substantive grounds for decision it chooses. ${ }^{93}$ Such a reading, however, would debase the meaning of Ashbacker, in which case the Commission had been willing to grant the unsuccessful applicant a full, though not effective, hearing. ${ }^{94}$ Citizens must protect more than the right to speak words which the Commission is free to ignore: little would be served by requiring the Commission to hear the challenger's proposals if, as a matter of policy, the Commission intends to renew the incumbent's license regardless of the challenger's merit. But, on the other hand, the Citizens court did not intend to require the Commission to hold a full comparative hearing every time a challenger filed an application; the court recognized that, under Storer, ${ }^{95}$ the Commission need not give an unqualified applicant a hearing. ${ }^{96}$ Evidently, the court was suggesting that the Commission may not decide a comparative renewal hearing solely on the basis of the incumbent's record, that a challenger does not become unqualified because the incumbent has an average record.

Although the court did not want to usurp the Commission's function of setting standards, it was nonetheless aware that it should not vacate the 1970 Policy Statement without giving the Commission some guidance regarding permissible standards. Implying that Johnston Broadcasting ${ }^{97}$ requires the Commission to weigh all relevant differences between the incumbent and the challengers in a comparative renewal hearing, the court stated that the Commission could place some, though evidently not controlling weight on the quality of the incumbent's operating record in resolving the comparative issue. A "superior record," the court said,

12447 F.2d at 1211. See text at note 14 supra.

${ }^{93}$ The Citizens court itself at one point claimed that the issue in the case involved the procedures, not the standards, employed by the Commission in comparative renewal hearings. $447 \mathrm{~F} .2 \mathrm{~d}$ at $1212 \mathrm{n} .34$.

"The court recognized that the situation in Ashbacker was not precisely parallel, as in that case the FCC had given the unsuccessful applicant a hearing on its merits. $447 \mathrm{~F} .2 \mathrm{~d}$ at 1211.

9s See text and notes at notes 16-21 supra.

96447 F.2d at 1212 n.34.

"7 447 F.2d at 1212-13. See text and note at note 18 supra. 
should be a "plus of major significance" and "[i]nsubstantial performance should preclude renewal."98 This formulation is analogous to the Commission's practice of granting preferences and demerits. ${ }^{99}$

The FCC, however, has misinterpreted the court's "plus of major significance" language, using it as a synonym for the invalid 1970 Policy Statement's "substantial service" test. ${ }^{100}$ The court contemplated that an incumbent would receive much credit in a comparative renewal hearing for having a superior record-credit that could prove decisive in a given case-but it did not contemplate that a strong record would obviate the need for a comparative inquiry. ${ }^{101}$

Apart from its remarks concerning the weight to be given an incumbent's record, the Citizens court did not give the Commission any more direct guidance regarding permissible standards. The court did imply that the Commission would be deficient if it only applied the standards from the 1965 Policy Statement because, as the court indicated, the incumbent's record is necessarily at issue in the comparative renewal hearing. However, the court did not indicate its opinion as to whether the structural policies could be applied at all in comparative renewal hearings and, assuming they could, whether the Commission can attempt to strike a balance between stability and restructuring. In light of the court's failure to probe the substance of the 1970 Policy Statement, it is unfortunate that it did not remand the Statement to the Commission for reconsideration and rulemaking, ${ }^{102}$ because after Citizens the Commission was left without a policy for comparative renewal hearings.

sx 447 F.2d at 1213.

"See note 23 supra.

100 A.H. Belo Corp., 40 F.C.C.2d 1131, 1133, 27 P \& F Radio REg. 2D 889, 892 (1973), on reconsideration, 47 F.C.C.2d 540, 30 P \& F Radio REG. 2D 975 (1974); Further Notice of Inquiry, in re Formulation of Policies Relating to the Broadcast Renewal Applicant, Stemming from the Comparative Hearing Process, 31 F.C.C.2d 443, 444-45, 43 P \& F Radio REg. Current Serv. 442, 442a-b (1971); Moline Television Corp., 31 F.C.C.2d 263, 268-69, 22 P \& F RADio REg. 2D 745, 752-53 (1971); see Geller, The Comparative Renewal Process in Television: Problems and Suggested Solutions, 61 VA. L. REv. 471, 487 (1975).

The court has declined to interfere in the Commission's process of defining "substantial service," stating that its suggested standards were not part of its mandate in the first Citizens opinion. Citizens Communication Center v. FCC, 463 F,2d 822 (D.C. Cir. 1972). For a discussion of the distinction between the court's and the Commission's approaches to this question, see note 149 infra.

101 The tenuousness of the distinction between a "plus of major significance" and a determinative test is emphasized by the fact that another panel of the Court of Appeals seems to have read Citizens to require a comparative hearing only when the incumbent's record fails the "superior service" test. Fidelity Television, Inc. v. FCC, 515 F.2d 684, 703 (D.C. Cir.), cert. denied, 96 S. Ct. 271 (1975).

102 The subject matter of the 1970 Policy Statement, profoundly affecting substantial 


\section{The Commission's Implementation of Citizens: RKO General}

The court's intention in striking down the 1970 Policy Statement in Citizens was to ensure that challengers would receive a fair hearing in a comparative renewal proceeding. In doing so, the court halted the Commission's progress towards identifying and articulating the unique policy problems presented by comparative renewal hearings without giving the Commission substantial guidance regarding the direction its policy should take. As a result of Citizens, the Commission is required to compare all qualified applicants in a comparative hearing on the basis of all the relevant criteria, ${ }^{103}$ but this requirement does not ensure that the challenger will receive a fair hearing. Experience shows that the Commission's latitude in making findings is so great ${ }^{104}$ and its discretion over the weight accorded to the criteria so broad that the Commission's decisions will invariably be affirmed if it at least pays lip service to all of the relevant criteria. ${ }^{105}$ Thus the result of Citizens has not been

interests of hundreds of broadcasters as well as the basic structure of the broadcast industry, is clearly appropriate for rulemaking, and would have given the court a record on which to judge whether too much consideration was given to the interests of incumbents. The leading commentator on rulemaking procedures has pointed out that: "When more than a handful of parties are affected, creation of new law through . . . administrative rule making is much more desirable than creation of new law through either judicial decision or administrative adjudication." K. Davis, Administrative Law Treatise $\S$ 6.15, at 283 (1970 Supp.). Prof. Davis has identified six specific grounds for preferring rulemaking procedures in cases such as this: (1) all interested parties are systematically notified; (2) tentative rules are available for study and comment before the decision is made; (3) by providing for wider participation by interested parties, rulemaking is more democratic than adjudication; (4) agencies are free to consult informally with helpful sources; (5) retroactive changes in the law are minimized; and (6) it provides a better basis for oversight by Congressional committees. Id. $\S 6.15$, at 284; cf. note 62 supra.

${ }^{103}$ For a detailed analysis and critique of the Commission's criteria, see Anthony, supra note 23 , at $26-60$.

10s Friendly, supra note 30, at 54, 59-60; Anthony, supra note.23, at 39-45; see text and notes at notes 106-26 infra.

${ }^{105}$ See, e.g., Pasadena Broadcasting Co. v. FCC, 35 P \& F Radio REg. 2D 47 (D.C. Cir. Sept. 24, 1975); WAIT Radio v. FCC, 418 F.2d 1153 (D.C. Cir. 1969), aff'd on subsequent appeal, 459 F.2d 1203 (D.C. Cir.), cert. denied, 409 U.S. 1027 (1972); Carroll Broadcasting Co. v. FCC, 258 F.2d 440 (D.C. Cir. 1958); Granik v. FCC, 234 F.2d 682 (D.C. Cir. 1956); Democrat Printing Co. v. FCC, 202 F.2d 298 (D.C. Cir. 1952). In his dissent in Fidelity Television, Inc. v. FCC, 515 F.2d 684, 705 (D.C. Cir.), cert. denied, 44 U.S.L.W. 3263 (U.S. Nov. 4, 1975), Judge Bazelon stated:

In an earlier day, this court tended to affirm comparative licensing decisions with only the most limited inquiry into the process of decision-making. If the FCC denominated the factors operative in its decisions with some reasonable clarity, this court would not intervene. . . . In recent years this court has, it appeared to me, moved away from this posture into a more demanding stance....

Id. at 705. Although the first part of this statement is undoubtedly true, the last seems wishful thinking. In support of the latter proposition, Judge Bazelon cited only three cases; none of 
to stop the Commission from applying the 1970 Policy Statement, but merely to stop it from admitting it is doing so. An examination of Fidelity Television, Inc. v. FCC, ${ }^{106}$ in which the Court of Appeals affirmed the Commission's decision in RKO General, Inc., ${ }^{107}$ the first comparative renewal hearing to reach the court since Citizens, will show this to be the case.

In Fidelity, the Court of Appeals affirmed the Commission's decision to renew the broadcast license of RKO General, Inc., whose subsidiary, $\mathrm{KHJ}-\mathrm{TV}$, operated the channel in question, and to reject the application of Fidelity Television, a locally-owned corporation. The court's seemingly unexceptionable holding was that the FCC, faced with a choice between two essentially equally qualified applicants for the same frequency, is justified in awarding the license to the incumbent in order to assure reasonable stability in the broadcast industry. ${ }^{108}$ However, the tortuous path followed by the Commission in determining that the two applicants were equal, ${ }^{109}$ and the Court of Appeals' uncritical approval of that conclusion, evoked sharp dissents in both bodies. The dissenters contended that the Commission, although nominally following Citizens, used its broad discretion in making comparisons effectively to eviscerate Fidelity's right to a fair hearing. ${ }^{110}$

The first issue raised in the comparative hearing in $R K O$

which truly support his position: WAIT Radio v. FCC, supra, in which the Commission originally did not hold a hearing at all and reached the same conclusion in the hearing held on remand, which was affirmed; Greater Boston Television Corp. v. FCC, 444 F.2d 841 (D.C. Cir.), cert. denied, 403 U.S. 923 (1971), discussed in note 74 supra; and Judge Leventhal's dissenting opinion in Star Television, Inc. v. FCC, 416 F.2d 1086, 1089 (D.C. Cir. 1969).

In fact, where the Commission has at least discussed the factors on which it relies, the Court of Appeals, following the lead of early Supreme Court opinions stressing the broad authority of the FCC, usually affirms after reciting the litany that the Commission has wide discretion in weighing comparative factors. See, e.g., FCC v. Allentown Broadcasting Co., 309 U.S. 134 (1939); Star Television, Inc. v. FCC, 416 F.2d 1086 (D.C. Cir. 1969); McClatchy Broadcasting Co. v. FCC, 239 F.2d 15 (D.C. Cir. 1956); Pinellas Broadcasting Co. v. FCC, 230 F.2d 2042 (D.C. Cir.), cert. denied, 350 U.S. 1007 (1956). Professor Davis has pointed out that one of the primary reasons courts avoid reviewing and reversing agency decisions is a "very common judicial psychology" that judges prefer not to try to review questions, such as the selection of broadcasters, that require expert technical knowledge. K. DAvis, ADMINISTRATive Law Treatise $\$ 28.16$, at 976 (1970 Supp.).

tos 515 F.2d 684 (D.C. Cir.), cert. denied, 44 U.S.L.W. 3263 (U.S. Nov. 4, 1975).

${ }_{107} 44$ F.C.C.2d 123, 28 P \& F Radio REG. 2D 1501 (1973).

tox 515 F.2d at 702,704 .

${ }^{109}$ See text at notes 111-24 infra.

"10 Although the Court of Appeals panel which heard the case voted unanimously to affirm, Judge Bazelon wrote a lengthy opinion stating his reasons for voting for hearing en banc. $515 \mathrm{~F} .2 \mathrm{~d}$ at 705. Commissioners Johnson and H. Lee dissented to the Commission's decision in separate opinions. 44 F.C.C.2d at 142, 28 P \& F RADto REG. 2 D at 1522. 
General related to the applicants' basic qualifications. General Tire and Rubber Co., the parent corporation of RKO, had recently been charged in an antitrust action brought by the Justice Department with engaging in reciprocal dealing in, among other things, television advertising time. Although the hearing officer specifically found that the licensee had participated in these activities, the Commission minimized the significance of this deficiency by noting that the illegality of these dealings had not been clear when committed." The Commission was not, however, so charitable in evaluating Fidelity's business practices. Fidelity was charged with failing to amend its application to reflect that one of its stockholders had acquired a small interest in some suburban newspapers. The Commission refused to reopen the record to take evidence on this contention, but nevertheless made use of it in the subsequent weighing of Fidelity's comparative strengths. ${ }^{112}$ In short, the Commission minimized the seriousness of KHJ's anticompetitive behavior and maximized that of Fidelity. ${ }^{13}$

The Commission then turned to KHJ's broadcast record, finding it mixed but average on balance. The Commission emphasized that KHJ had accurately reported its programming and had substantially implemented the proposals it had made in its original application, proposals which were at that time considered to be in accordance with the public interest. ${ }^{114} \mathrm{KHJ}$ was precisely the kind of operator the Commission is loathe to disturb and replace with an untested applicant-an average but honest performer.

Fidelity's case may well have been lost at this point. But under Citizens, the Commission was required to conduct a full comparative hearing. Fidelity was clearly superior to KHJ on the compara-

II 44 F.C.C.2d at 128-30, 28 P \& F RADIo REG. 2D at 1509-11.

11244 F.C.C.2d at 177-78, 16 P \& F Radio REG. 2D at 1214.

${ }^{113}$ The Hearing Examiner found a clear pattern of reciprocal dealing and concluded that it was contrary to the public service purposes for which licenses are issued, caused unfair competition to independent broadcasters, resulted in overcommercialization of KHJ's air time, and reduced incentives for good programming. 44 F.C.C.2d at 221-23, 16 P \& F RaDio REG. 2D at 1264-66. The Commission discussed none of these points. Two of the Commissioners, in dissent, thought that $\mathrm{KHJ}$ should have been disqualified as a licensee entirely for this behavior. 44 F.C.C.2d at 141, 144, 28 P \& F Radio REG. 2D at 1521, 1525.

I1 44 F.C.C.2d at 130-32, 28 P \& F Radio REG. 2D at 1513-15. The opinion at this point illustrates the inherent advantage of having a record to run on. The FCC, like the Hearing Examiner, listed the various public interest programs KHJ had aired, but where the Examiner had gone on to weigh those programs against the rest of KHJ's broadcast record, 44 F.C.C.2d at 220-21, 16 P \& F RADIo REg. 2D at 1262-64, the Commission was content to let the list of the station's accomplishments determine the issue, remarking that the station could not be expected to please everyone. 44 F.C.C.2d at 131-33, 28 P \& F RADIo REG. 2D at 1513-14. 
tive structural criteria of integration and diversification. RKO's owner, General Tire and Rubber Co., has its headquarters in New York and Ohio; at the time of the hearing it held 18 licenses in addition to $\mathrm{KHJ}$, as well as other media interests. ${ }^{115}$ Fidelity was owned entirely by local residents, none of whom had any significant other media interests. Two of its stockholders, owning together 22.6 percent of its stock, proposed to work full-time in the station. ${ }^{116}$ The Commission nevertheless managed to find the two applicants essentially equally qualified.

The Commission relied on the earlier character issue to narrow the gap between the applicants on the diversification issue. It reduced Fidelity's advantage because one of its stockholders had acquired another media interest, despite the lack of evidence on the point ${ }^{117}$ and though Fidelity claimed that the interest in question was that of a minor stockholder in a weekly advertising "shopper."118 KHJ's disadvantage, on the other hand, was reduced because the Commission found that RKO General had not interfered with the autonomy of the station management; the reciprocal dealing was ignored. ${ }^{19}$ The Commission stated further that any diversification advantage enjoyed by Fidelity would not be controlling because there were numerous other broadcast facilities in the area and because the Commission opposed restructuring the broadcast industry through comparative renewal hearings. ${ }^{120}$ This argument could potentially undermine the Citizens decision; if the Commission can declare that any comparative criterion is irrelevant in a comparative renewal hearing, eventually it could be left with only the adequacy of the incumbent's record as a basis for decision, in direct conflict with Citizens.

The final issue was the best practicable service criterion, which in this case only involved integration. The Commission found that RKO had achieved the functional equivalent of integration by giving the station management autonomy in programming and requiring the managers to participate in local civic affairs. ${ }^{121}$ It reached

115 44 F.C.C.2d at 153-54, 16 P \& F Radio Reg. 2D at 1186-87.

it Id. at 188-89, 16 P \& F RADIO REg. 2D at 1228-29. The Hearing Examiner gave Fidelity a demerit on integration, evidently not believing its proposal. The Commission ignored the Examiner's finding on this point, but the Court of Appeals reinstated the Examiner's finding as its ground for affirming the Commission's decision. 515 F.2d at 700, 701.

1144 F.C.C.2d at 133-34, 28 P \& F Radio REg. 2D at 1514-15.

118447 F.2d at 701 n.42. The court regarded the use of the interest to downgrade Fidelity's diversification preference as "harmless error."

"1' 44 F.C.C.2d at 133-34, 28 P \& F RADio REg. 2D at 1514-15; see note 113 supra.

$120 \mathrm{Id}$.

121 Id. at 136, 28 P \& F RAdIo REg. 2D at 1517. 
this conclusion even though the Hearing Examiner had found that the station had repeatedly scheduled excessively violent films despite widespread community protest, the very type of insensitivity to community opinion the integration criterion should act to eliminate. ${ }^{122}$ Even assuming its finding to be correct, however, the Commission was, as with the diversification issue, refusing to compare the applicants on the grounds that its comparative criteria do not justify displacing an incumbent in RKO's position. In then assessing Fidelity's strength on the integration issue, the Commission again used the issue it had declined to order evidence taken on. It asserted that Fidelity's failure to make timely notification of changes in its media interests gave rise to the suspicion that its integration proposals were not made in good faith, and consequently reduced its advantage. Thus, no preference was awarded on the integration criterion, ${ }^{123}$ causing Judge Bazelon to characterize the hearing as bearing "the stench of procedural bias."124

In sum, the central flaw in RKO General is that the Commission simply refused to compare the applicants at all. The Commission claimed to base its decision on the policy preference for incumbents over challengers when no substantial difference appears between them. ${ }^{125}$ It did so, however, only after dismissing as inapplicable all of the criteria it normally uses to measure the differences between applicants because one applicant was a renewal candidate with an acceptable record of service. Had the Commission, without taking any evidence on Fidelity's application, examined RKO's record and determined that it was within the bounds of average performance, announced that the diversification criterion was not relevant because $\mathrm{KHJ}$ was autonomous in its programming and in a diverse broadcasting market, and that integration was not relevant because KHJ's management was the functional equivalent of local owner-operators, and thereupon renewed RKO's license, it would clearly have violated Citizens. Instead, the Court of Appeals affirmed when it took the same three findings, interspersed them

122 Id. at 177-88, 16 P \& F RADio REG. 2D at 1214-28. The Examiner found that a "respectable and substantial body of community opinion . . . voiced disapproval . . . [and their] disapproval fell on deaf ears. The protests . . . appear to have been met only by a gratuitous exhibition of arrogance... . The licensee attitude thus reflected does not measure up to that sense of licensee responsibility to the public the Commission has a right to expect from those whom it franchises." Id. at 221, 16 P \& F RADIo REG. 2D at 1263. See also note 113 supra.

123 44 F.C.C.2d at 135-36, 28 P \& F RADio REG. 2D at 1516-17.

124 515 F.2d at 717 (Bazelon, J., dissenting).

12544 F.C.C.2d at 137, 28 P \& F Radio REG. 2D at 1518-19. This was the main point on which the court affirmed. 515 F.2d at 704-05. 
through a hearing in which it noted Fidelity's advantages, denigrated them through the use of charges on which it had not taken evidence, and refused to give them any decisional significance. If ever a hearing deserved the appellation "an empty thing," it was surely that afforded Fidelity. ${ }^{26}$

\section{A Proposed Model for Comparative Renewal Hearings}

Given the Commission's unwillingness or inability to apply the standard comparative issue properly to incumbents with acceptable broadcasting records, it is tempting to agree with those who argue that the procedure should not be employed at all, or should be limited to the situation in which the challenger can demonstrate a need for a change due to misconduct on the part of the incumbent. ${ }^{127}$ Proponents of the comparative renewal process have advanced two arguments ${ }^{128}$ in support of it: first, the threat of potential challengers encourages licensees to strive to render the best possible service; ${ }^{129}$ second, it provides a mechanism whereby social groups-particularly racial minorities-previously excluded from ownership of stations can gain access to the airwaves. ${ }^{130}$ In addition, we have seen that the 1965 Policy Statement allocates licenses on the basis of policies regarding the structure of the industry; presumably if these policies are important enough to justify basing all original license allocations on them in comparative cases, there is

${ }^{126}$ For a more detailed critique of Fidelity and $R K O$, see Judge Bazelon's dissent, 515 F.2d at 705-21

${ }^{127}$ Insofar as the comparative renewal procedure encourages applicants to become private attorneys general and uncover misconduct by licensees that has escaped the notice of the Commission, the procedure serves a valuable function, particularly since groups seeking to challenge a license renewal without the incentive of seeking the license themselves face high costs and unsympathetic Commission procedures. See Office of Communication of the United Church of Christ v. FCC, 425 F.2d 543 (D.C. Cir. 1969). Further, the presence of another qualified applicant ready and willing to provide service to an area can encourage the Commission to deny renewal to a licensee whose performance, although substandard, is not egregious enough to warrant the drastic step of decreasing the amount of service available to an area by a flat denial of renewal. See Star Stations of Indiana, Inc., 51 F.C.C.2d 114, 26 P \& F RADio REc. 2D 1101 (Admin. Law Judge 1973), rev'd in part, 51 F.C.C.2d 95, 32 P \& F RADIO REg. 2D 1137 (1975).

${ }^{128}$ The Citizens court invoked both these arguments in dicta. $447 \mathrm{~F} .2 \mathrm{~d}$ at $1206,1213 \mathrm{n} .36$, 1214.

129 Thus the supporters of the comparative renewal procedure have relied primarily on the failure of the FCC to adequately review licensee performance at renewal. See generally Comment, Media Reform Through Comparative License Renewal Procedures: The Citizens Case, 57 Iowa L. Rev. 912 (1972); Chicago Comment, supra note 5; Comment, The Aftermath of WHDH: Regulation by Competition or Protection of Mediocrity? 118 U. PA. L. Rev. 368 (1970).

${ }^{130}$ Hearings, supra note 66 , at $610-13$. 
some public interest in bringing nonconforming parts of the industry into line with them.

An examination of these arguments will show, however, that the interests stressed would not be served by the application of the Commission's ordinary comparative criteria to all comparative renewal situations. The first argument, the so-called "competitive spur" theory, is based on a misunderstanding of the 1965 Policy Statement. Incumbents can only "compete" with challengers if the Commission attempts to predict whether the incumbent or the challenger would provide better service, which it does not and probably cannot do. The only competition that would be spurred by an application of the 1965 Policy Statement to comparative renewal hearings would be competition to design a corporate structure which fits the FCC's model; many incumbents locked into a corporate structure which can be "improved" only with great difficulty would be seriously disadvantaged. The comparative renewal process can only provide a programming spur to incumbents if the Commission threatens to compare incumbents with challengers on the basis of the 1965 Policy Statement, and then exempts those incumbents which achieve a certain level of performance-the approach struck down in Citizens when based on average performance.

The 1965 Policy Statement is likewise a poor tool to promote minority access to the airwaves simply because its sweep is too wide. Minority access is a special issue raising many difficult policy questions; it will not be raised in all cases and the 1965 Policy Statement was not designed to deal with it. And finally, although there may be some public interest in retroactive application of the diversification-integration policies, the 1965 Policy Statement itself provides no means for determining the threshold question of whether its criteria should be applied retroactively at all-that is a policy question which the Commission must make separately, weighing the public interest in diversification-integration against that in stability.

None of the unique issues raised by a comparative renewal hearing are really "comparative" at all, in that none of them can be resolved by a comparison of incumbents and challengers on the basis of characteristics which both have. Thus, the first requirement of a rational comparative renewal policy must be that it recognize that allocation decisions must often be made on the basis of characteristics unique to one of the applicants, on the grounds that the public interest in fostering stations with such characteristics may be more important than the outcome of the standard comparative issue. In designing such a policy, it will be helpful first to examine briefly other situations in which the Commission makes license allocations on noncomparative grounds. 


\section{A. Basic Qualifications and the 307(b) Issue}

Before reaching the comparative issue, the Commission's practice is first to determine whether there are any noncomparative policy grounds for decision. In setting such policies, which are based on the Commission's authority to adopt rules governing the broadcast industry, ${ }^{131}$ the Commission generally utilizes notice-andcomment rulemaking procedure. In applying the policies to individual cases, it performs a purely adjudicatory function. The process is thus much less amorphous and subjective than resolution of the standard comparative issue.

The Commission has promulgated noncomparative regulations that concern such important matters as the allocation of frequencies among geographical areas and different types of broadcast facilities $^{132}$ and the setting of basic qualifications for licensees. ${ }^{133}$ The Commission has adopted rules providing for automatically denying without hearing applications of multiple-licensees for additional licenses, ${ }^{134}$ reallocating occupied frequencies to other communities, ${ }^{135}$ and automatically denying applications for stations that would cause interference, either electrical or financial, with preferred types of stations. ${ }^{136}$ These rules have all received judicial approval. In all of these situations, applications are denied in favor of other applicants, either present or anticipated, without a hearing in which the rejected applicant can present the merits of its proposal; thus Ashbacker, strictly speaking, is violated. Nevertheless, the public interest in the development of uniform regulatory policies governing

13147 U.S.C. $\$ 303$ (1970). See National Broadcasting Co. v. United States, 319 U.S. 190 (1943).

${ }^{132}$ See 47 C.F.R. $\$ \S 2.102,2.104,2.106$ (1973); 47 U.S.C. $\S \S 303(a)(d)(1970)$.

1347 U.S.C. $\S 303(l)(1970)$. The Commission's power to set qualifications for licensees is broad, and includes the authority to disqualify applicants on public policy grounds not directly related to ability to operate a station. United States v. Storer Broadcasting Co., 351 U.S. 192 (1956); see text at notes 172-75 infra. However, an applicant must be given an opportunity to show why such a policy should not apply to it, and a hearing is required if the applicant's showing is sufficiently strong. See, e.g., WAIT Radio v. FCC, 418 F.2d 1153 (D.C. Cir. 1969) aff'd on subsequent appeal, 459 F.2d 1203, cert. denied, 409 U.S. 1027 (1972); City of New York Municipal Broadcasting System v. FCC, 223 F.2d 637 (D.C. Cir. 1955).

${ }^{134}$ United States v. Storer Broadcasting Co., 351 U.S. 192 (1956).

135 Goodwill Stations, Inc. v. FCC, 325 F.2d 637 (D.C. Cir. 1963); Transcontinent Television Corp. v. FCC, 308 F.2d 339 (D.C. Cir. 1962).

136 WLVA, Inc. v. FCC, 459 F.2d 1286, 1304 (D.C. Cir. 1972) (rule denying application for VHF channel in area reserved for UHF development upheld against argument it violated Ashbacker); 560 Broadcasting Corp. v. FCC, 418 F.2d 1166 (D.C. Cir. 1969) (application of freeze on new nighttime AM stations in areas already receiving AM nighttime service upheld despite contention that area's only AM service originated in another city and was not oriented toward local concerns). 
the growth and structure of the industry has consistently been held to be superior to the right of individual applicants.

In another situation the Commission grants the applicants a hearing but may allocate the license on the basis of structural policies without reaching the standard comparative issue. This is the socalled 307(b) issue, which arises when the Commission is faced with mutually exclusive applications by qualified applicants who propose to serve different communities. ${ }^{137}$ The applicants in a $307(\mathrm{~b})$ issue are compared in order for the Commission to fulfill its statutory mandate to allocate licenses so as to promote the "fair, efficient and equitable distribution of radio service" among "the several States and communities." 138 The criteria used concern the allocation of stations among communities according to the communities' needs rather than the merits of the individual applicants. After taking evidence on the population and degree of community identification in the affected areas, ${ }^{139}$ the Commission selects the applicant that will best effectuate the goals of providing at least one

${ }^{137}$ See Anthony, supra note 23, at 85 n.424. The Commission, however, prefers to make use of rulemaking to allocate channels. See, e.g., In re Amendment of FM Channel Assignments, 4 F.C.C.2d 525, 5 P \& F Radio REG. 2D 1530 (1965).

${ }^{13 x} 47$ U.S.C. $\S 307$ (b) (1970).

139 See, e.g., Rockland Broadcasting Co., 36 F.C.C. 303, 2 P \& F Radio REg. 2D 39 (Rev. Bd. 1964), aff'd, 36 F.C.C. 1510, 2 P \& F RAdio REG. 2D 820 (1964). In cases involving the question of whether a suburb is a separate community for purpose of the $307(b)$ issue, the Commission has established a rebuttable presumption that a proposed suburban station whose signal contour would penetrate the central city to a significant degree will, for the purposes of basic signal-strength qualifications and the $307(\mathrm{~b})$ issue, be considered as servicing the city itself. Policy Statement on Section 307(b) Considerations for Standard Broadcast Stations Involving Suburban Communities, 2 F.C.C.2d 190, 6 P \& F RADIo REG. 2D 1901 (1965), aff'd, Northeast Broadcasting Co. v. FCC, 400 F.2d 749 (D.C. Cir. 1968).

Where the proposed signals of two stations will cover approximately the same area, the Commission does not consider their point of origin as controlling in a 307(b) issue. See Goodman-Todson Broadcasting, Inc., 45 F.C.C.2d 573, 28 P \& F RaDio REG. 2D 1597 (1973), rev'd on other grounds sub nom. Pasadena Broadcasting Co. v. FCC, No. 74-1012, -1019, -1033, -1034, -1454 (D.C. Cir. Sept. 24, 1975), 35 P \& F Radio Reg. 2D 47.

The $R K O$ case involved 307 (b) considerations. Fidelity proposed primarily to serve an area near Los Angeles, called "the Southland," the needs of which it asserted were neglected by the Los Angeles stations. It requested hearings on a 307(b) issue and a "service philosophy" comparative issue, both of which were denied. RKO General, Inc., 5 F.C.C.2d 517, $8 \mathrm{P}$ \& F RADio REG. 2D 957 (1966). Judge Bazelon conceded that Fidelity had failed to make the showing that the Southland was a separate community for a 307(b) issue, but argued that the failure to consider the service philosophy issue was unjustified. Fidelity Television, Inc. v. FCC, 515 F.2d 684, 721-25 (D.C. Cir. 1975), cert. denied, 44 U.S.L.W 3263 (U.S. Nov. 4, 1975). Although the Commission's treatment of this issue may indicate a need for a more flexible approach to the 307 (b) issue to insure that distinct communities within a metropolitan area are able to obtain service oriented toward their problems and interests, the Commission is justified in not wishing to base allocation decisions on "service philosophy" in light of its experience under Tampa Tribune. 
broadcast service for all persons, maximizing the number of station choices available to service areas and providing a locally-operated station for as many communities as possible. ${ }^{140}$ In brief, the Commission has determined, as a matter of policy, that a station which would provide average, but the only, service for an area is to be preferred over an applicant which is likely to provide excellent service to an area already well-served by other stations. ${ }^{141}$ This procedure was approved by the Supreme Court in FCC $v$. Allentown Broadcasting Co. ${ }^{142}$ where, in reversing the Court of Appeals, the Court observed that the procedure kept "the needs of the community" from being "subordinated to the ability of an applicant for another locality." 143

The Commission's 307(b) criteria have escaped the scathing criticism directed at its standard comparative issue criteria. ${ }^{144}$ It seems clear that the 307 (b) issue is more capable of fair and objective application and that it is entirely reasonable for the Commission to dispose of applications on 307(b) grounds where appropriate without comparing the merits of the applicants. The success of this procedure suggests that when the Commission can reasonably resolve a comparative hearing on the basis of a public need for a type of broadcasting service that only one applicant will provide, such disposition is preferrable to application of the standard comparative issue. This type of procedure should be the foundation for a revamped comparative renewal hearing.

\section{B. Issues in a Comparative Renewal Hearing}

After assuring itself that both applicants are qualified, the Commission should first determine whether any policy grounds call for awarding the license to either the incumbent or to the challenger; if so, the hearing would terminate. If not, the Commission should proceed to the standard comparative issue, but should treat the two as equals; the incumbent's record should be irrelevant at

110 See First Report and Order, in re Revision of FM Broadcast Allocation Rules, 33 F.C.C. 309 (1962).

I' See, e.g., Meredith Colon Johnston, 18 F.C.C.2d 168, 16 P \& F Radio REg. 2D 491 (Rev. Bd. 1969); Albuquerque Broadcasting Co., 25 F.C.C. $683,785-87,16$ P \& F RAdIo REg. 765, 856-57 (1958), aff'd sub nom. American Broadcasting-Paramount Theatres, Inc. v. FCC, 280 F.2d 631 (D.C. Cir. 1960).

142349 U.S. 358 (1955).

143 Id. at $361-62$.

14 For example, the most carefully detailed indictment of the modern comparative hearing system extant devotes only three pages to $307(\mathrm{~b})$ issues, with no criticisms. Anthony, supra note 23 , at $85-87$. 
this point because the Commission no longer seriously attempts to predict licensee performance through the standard comparative issue $^{145}$ and it has already been determined that no noncomparative policy favors retaining the incumbent. Two broad noncomparative policies could be considered: promoting stability in the broadcast industry, and providing access to broadcast facilities to excluded segments of the population. The first pulls towards granting the licensee's renewal application, the second ordinarily towards the challenger. Other policies could be revealed in the course of rulemaking.

1. Stability. At the outset, a distinction must be drawn between the public's interest in stability and the individual stations' interest in retaining their licenses. The Commission's policies in the past have been too solicitous of the latter under the guise of concern for the former. The Communications Act expressly states that licensees acquire no interest in the use of a frequency beyond the terms of their licenses. ${ }^{146}$ Thus a stability policy is a legitimate basis for license allocation only to the extent that it protects the public from a reduction in the level of service.

The stability policy is properly based on the perception that in some circumstances the public interest is best served by giving incumbents a reasonable expectation that their licenses will be re-

its This discussion assumes the standard comparative issue will be comprised of the present structural integration and diversification policies. See note 62 supra.

Is6 47 U.S.C. $\S 309(\mathrm{~h})(1970)$. Although some contrary judicial authority exists, the predominant, and correct, position has been stated by the Court of Appeals: "The public interest is not disturbed if A is destroyed by B, so long as B renders the required service." Carrol Broadcasting Co. v. FCC, 258 F.2d 440, 444 (D.C. Cir. 1958). Carroll is the leading case on whether the FCC may consider economic harm to existing stations in an advertising market in determining whether to license a new station. The court held that the Commission must do so when, and only when, the potential harm is great enough to cause an overall decrease in the level of service available to the area. It thus reconciled FCC v. Pottsville Broadcasting Co., 309 U.S. 134, 136 (1939), in which the Supreme Court observed that since broadcasting obviously requires a large eapital investment which is threatened by the three-year licensing scheme, Congress must have intended for some instability in the industry, with FCC v. Sanders Bros. Radio Station, 309 U.S. 470 (1940), in which the Court held that the Commission may consider economic injury to broadcasters when it affects the public interest.

Some implicit support for the concept of rights and equities flowing from prior possession of a license may be found in the handful of cases dealing with comparative hearings in which one of the applicants has been operating on the frequency in question on a four-month temporary license. See Greater Boston Television Corp. v. FCC, 444 F.2d 841, 853-55 (D.C. Cir.), cert. denied, 403 U.S. 923 (1971); Community Broadcasting Corp. v. FCC, 363 F.2d 717, 720-22 (D.C. Cir. 1966); South Fla. Television Corp. v. FCC, 349 F.2d 971, 972 (D.C. Cir.), cert. denied, 382 U.S. 987 (1965). These decisions should not, however, be read as establishing any absolute right to renewal expectations, but simply as holding that having set down standards to apply to renewal candidates, the Commission may not arbitrarily refuse to apply them to one who seeks renewal. See also Chicago Comment, supra note 5, at 862-66, 871. 
newed without a challenge on the 1965 Policy Statement criteria. The major broadcasting corporations-which are relatively unintegrated and undiversified-have made the long-term investments necessary for the development of high quality modern broadcasting largely because they were confident of renewal. The quality of those broadcasters' programming will undoubtedly decline if they cannot be assured of renewal despite their structural disadvantages. ${ }^{147}$ Although it is obviously in the public interest to encourage such investments, a stability policy must be designed so as to protect only those incumbents who have actually made use of their assurance of renewal to provide superior broadcasting.

The Commission's current approach to stability, as manifested in the 1970 Policy Statement and its subsequent rulemaking procedure, ${ }^{148}$ is not properly designed to serve this policy. The Commission has attempted to establish uniform, industry-wide standards, compliance with which would entitle an applicant to renewal on stability grounds. But the standard as designed can be readily met by average licensees, and is thus an inappropriate basis for preferring incumbents, since an otherwise qualified challenger would presumably be just as capable of meeting the normal industry standard. If the level of service to be provided is the same, the public interest is better served by having the service provided by the station which best meets the Commission's structural criteria. An in-

11: The lack of renewal expectations also arguably discourages investment in the industry and thus prevents the expansion of service to underserved areas. This argument applies primarily to small, unprofitable broadcasting markets where a station might have to struggle along for several license terms before becoming profitable. See Hearings, supra note 66, at 22. Licenses for stations in the established markets, which are usually the subject of comparative challenges, are enormously profitable, according to some studies, returning over twice their depreciated investment in a single three-year license term. See Broadcasting in America and the FCC's License Renewal Process: An Oklahoma Case Study, 14 F.C.C.2d 1, 14 (1968) (statement by Cox \& Johnson, Comm'rs); Hearings, supra note 66, at 114. Thus, although the Commission should give licensees struggling to establish a station in an underserved area some expectation of renewal in order not to discourage investment in such stations, there is little or no justification for doing the same on these grounds in an established and profitable market, since there is little danger that frequencies in such areas would be unoccupied as a result.

The Commission has rejected such dual treatment, stating "certainly, it would make no sense to apply the [1970] policy statement only to losing operations and to deny its benefits to any station which is operating in the black. This would hardly be an inducement to good operation." Petitions for Rulemaking, in re Policy Statement Concerning Comparative Hearings Involving Regular Renewal Applicants, 24 F.C.C.2d 383, 384-85 (1970) (reconsideration denied). The Commission's argument appears to be that the policy proposed would induce licensees to run an unprofitable station, so that they could be assured of retaining their licenses and lose even more money in the future, which hardly seems likely.

16x See text and notes at notes 81-84 supra. 
cumbent should be preferred on stability grounds only when its record demonstrates broadcasting service superior to that which could have been provided by a licensee not assured of renewal. ${ }^{149}$

While a superior record is a strong factor in favor of an incumbent, it should not be dispositive. Other noncomparative issues could outweigh it. ${ }^{150}$ However, an incumbent with an inferior record should automatically be disqualified. Given the crowded condition of the frequencies, if a licensee fails to meet even average service standards, its frequency should, if possible, be awarded to another qualified applicant. In this area, the Commission's "substantial service" standards ${ }^{151}$ could form the minimum threshold of quality necessary to withstand comparative renewal challenge.

If this initial inquiry does not produce either a finding of superior or insubstantial service, no further consideration should be given to the incumbent's record. The standard comparative issue would then come into play (unless the access issue were dispositive) and the incumbent's record becomes irrelevant. Although ignoring

19 The problem of defining the level of service which should warrant renewal is the most difficult problem posed by this approach. Ideally, there should be no fixed standard. The Commission's task should be to distinguish between stations which provide the minimum level of broadcasting service which is required of them, which it can be assumed that any station would do, and stations which make use of their expectancy of renewal to do more than just what is required of them to improve the quality of their programming. The focus should be not on what level of service is achieved, but on whether the licensee has passed up opportunities for public-interest programming in order to maximize short-term profit. No public interest is served by giving such a broadcaster an expectation of renewal, as it will not affect its conduct. Nevertheless, all broadcasters, no matter how public-spirited, have a legitimate interest in knowing the Commission's expectations, and consequently there will he a natural tendency for some kind of uniform standards to evolve. The Commission's current approach makes an easily-attainable percentage of public-interest programming the only requirement for renewal and makes no effort to distinguish between the licensee that meets that standard as a normal cost of doing business and the licensee that goes beyond the standard and actively seeks to do all it can to improve its service. The public interest requires that only the latter be assured of renewal.

In order to make this distinction, it will probably be desirable for the Commission to focus not so much on the output of stations as on their management policies, to determine which stations are actually making use of their renewal expectancies in the public interest. The Citizens court seemed to be looking to this approach when it suggested that the Commission examine the percentage of profits a station had reinvested in programming improvements. 447 F.2d at 1213 n.35. This suggestion has been rejected by the Commission, Southern Broadcasting Co., 34 F.C.C.2d 908, 24 P \& F Radio REc. 2D 296 (Rev. Bd. 1972), but the possibility is clearly one which should be examined if the Commission were to adopt the approach suggested here. In addition, such a criterion would have the desirable effect of encouraging the major broadcasting corporations to reinvest a greater share of their profits in programming, with corresponding benefits to the public.

${ }_{1 \times 1}$ Actually, as in the basic qualifications, the challenger may be entitled to demonstrate that this rule should not be applied to it. See note 133 supra.

15 See notes 100-02 supra. 
a licensee's record in deciding on renewal seems intuitively unsound, and it clearly goes against the Commission's grain, ${ }^{152}$ it has been shown how the consideration of incumbents' records distorts the comparative criteria. ${ }^{153}$ Further, the exclusion of the incumbent's record follows logically from the structure of the proposed hearing procedure. The record is relevant only to predicting the level of service to be rendered in the future, which, since 1965, is not at issue in the standard comparative issue. ${ }^{154}$ If only superior incumbents are to be accorded any renewal expectancy, and the incumbent has already been found not to be superior, then its record no longer possesses decisional relevance.

It must be recognized, however, that this procedure could be exploited by what turns out to be an inferior broadcaster which tailors its application in accordance with the comparative criteria in order to displace an incumbent whose service, while not warranting renewal on the basis of the stability issue, is at least average. This problem, however, is not unique to the comparative renewal procedure, but is inherent in the Commission's inability to predict licensee performance; the dimensions of the problem can be attributed to the Commission's failure to monitor the performance of its licensees effectively. ${ }^{155}$ To prevent replacing licensees that have provided adequate service in the past with inferior broadcasters, the Commission could in this situation use its power to grant conditional licenses. ${ }^{156}$ For example, if the basis for the challenger's superiority is a superior integration showing, the Commission could make its license conditional on the requirement that it make no

152 But see Mid-Florida Television Corp., 33 F.C.C.2d 1, 23 P \& F Radio Reg. 2D 521 (Rev. Bd. 1972), rev'd sub nom. TV 9, Inc. v. FCC, 495 F.2d 929 (D.C. Cir.), cert. denied, 419 U.S. 986 (1974). See also Lamar Life Broadcasting Co., 24 F.C.C.2d 618, 19 P \& F RADio REg. 2D 851 (1970).

Is See text and notes at notes 106-26 supra. As Chief Justice, then Judge, Burger pointed out in an early case: "To argue . . . that [consideration of an incumbent's prior operation of a facility] may weigh in the balance of an otherwise close question is not a challenge to the good faith of the triers; it is a recognition that they are mortal men." Community Broadcasting Co. v. FCC, 274 F.2d 753, 759 (D.C. Cir. 1960).

1si Under the 1965 Policy Statement, the incumbent's record is mildly relevant to the integration criterion in that experience of the applicant's owners, as opposed to the record of the applicant itself, is considered. 1965 Policy Statement, supra note 22, at 396, 5 P \& F RADIO Rrc. 2D at 1910-11. The significance of this factor must be kept carefully in check to prevent indirect distortion of the comparative criteria. Cf. Community Broadcasting Corp. v. FCC, 363 F.2d 717, 721 (D.C. Cir. 1966) ("experience" and "past performance" contrasted).

${ }^{155}$ See text and note at note 66 supra.

${ }_{156}$ The Commission has authority to prescribe conditions in licenses, 47 U.S.C. $\$ \S 303(\mathrm{r})$, 309(h) (1970), and to revoke licenses for failure to comply with such conditions, 47 U.S.C. \& 312(a) (1970). See Anthony, supra note 23, at 91-97. 
material changes in its station management without Commission approval. Similarly, a challenger that prevailed on diversification grounds could be forbidden from acquiring any other media interests, or a challenger that prevailed on the standard comparative issue could be forbidden from transferring its license to a less qualified broadcaster. ${ }^{157}$ These possibilities should be carefully explored by the Commission in rulemaking proceedings, with care taken that the procedures developed do not have the effect of unduly discouraging legitimate challenges.

2. Access. A second possible threshold standard, based on the policy of providing access to the broadcast industry to segments of the population not currently served, has three facets: providing minority group access to communications facilities, allocating frequencies for specialized programming, and 307(b) considerations, previously considered in another context. ${ }^{158} \mathrm{~A}$ strong showing on any of these issues could balance out a strong stability showing and require resort to the standard comparative issue, or could entitle a challenger ${ }^{159}$ to receive a license over an incumbent that had not made a strong showing on the stability issue.

a. Minority Group Access. The issue of providing access to communications media for minority groups raises very troubling first amendment questions. ${ }^{160}$ A policy of allocating licenses within an area in accordance with the demographic makeup of that area would alleviate these problems to some extent. There would be a reduced need for the Commission to try to compel, for example, white media owners to serve the interest of the black community, ${ }^{161}$ since minority group members would presumably have ready access to the airwaves.

Granting a preference to applications filed by members of racial and ethnic minorities entails formidable difficulties, however, and the Commission has tended to avoid doing so $^{162}$ even in the face of

157 Commission approval, governed by the public interest, convenience and necessity standard, is required for the transfer of licenses. 47 U.S.C. $\S 310(d)$ (1974 Supp.).

${ }_{15 x}$ See text and notes at notes 139-44 supra.

159 Theoretically, of course, there is no reason why any of the considerations described in this section could not favor the incumbent, and the incumbent would be free to urge any of them. However, it is unlikely that a challenger would attempt to displace a licensee who not only was supported by the stability issue but by some other structural policy.

${ }_{150}$ See Karst, Equality as a Central Principle in the First Amendment, 43 U. CHI. L. Rev. 20, 43-52 (1975).

${ }^{161}$ See, e.g., Alabama Educ. Television Comm'n, 50 F.C.C.2d 461, 32 P \& F Radio Reg. 2D 539 (1975).

162 The Commission has recently declined to incorporate any special consideration for minority ownership into its station allocation rules. Report and Order, in re Amendment of 
growing judicial pressure. ${ }^{163}$ Following dicta in Citizens, ${ }^{164}$ for example, the Court of Appeals, in TV 9, Inc. v. FCC, ${ }^{165}$ remanded a comparative hearing decision in which the Commission had refused to give any consideration to the fact that one of the applicants included a substantial number of black persons in its ownership and management structure. Thus, the Court of Appeals has recognized a public interest in providing licenses for certain social groups ${ }^{166}$ which the Commission could apply as it currently applies the 307(b) issue to provide licenses to geographic communities.

Two special problems would arise by employing the access issue as a preliminary noncomparative question. First, even though a minority owned station may be entitld to some frequency in an area, it does not necessarily follow that the public interest would be served by giving it any particular incumbent's frequency. The Commission could examine major service areas in which the license allocation structure does not reflect the social structure, determine how many frequencies should be allocated to minority broadcasters, and make them available by refusing renewal to the licensees with the worst records.

It would be difficult, however, for the Commission to make such a determination: the comparative criteria of the 1965 Policy Statement would not be relevant because the issue is responsiveness to the programming needs of a particular community; if the Commission were to attempt to make such a determination, it would have to develop a new mechanism which would necessarily tax further its already strained resources. When such a challenge is made, moreover, it is reasonable to expect that the challenger will go after the station in the area with the worst record. ${ }^{167}$ Since a challenger would probably study the records of the various incumbents very

Part 73 of the Commission's Rules Regarding AM Station Assignment, 54 F.C.C.2d 1, 22, 34 P \& F Ranio RfG. 2D 603, 626 (1975); cf. Mid-Florida Television Corp., 33 F.C.C.2d 1, 17-18, 23 P \& F Ranio Rfg. 2D 521, 542-44 (Rev. Bd. 1972), rev'd sub nom. TV 9, Inc. v. FCC, 495 F.2d 929 (D.C. Cir.), cert. denied, 419 U.S. 986 (1974). The Commission has taken service to minority groups into account in consideration of applications to expand service, where it has an existing record of such service to examine. See, e.g., Mel-Lin, Inc., 22 F.C.C.2d 165, $18 \mathrm{P}$ \& F Ranio Rrg. 2n 787 (1970).

143 See generally 52 Tex. L. Rev. 806 (1974).

161 See note 128 supra.

INi 495 F.2d 929 (1973).

ins The dicta in Citizens, $447 \mathrm{~F} .2 \mathrm{~d}$ at $1213 \mathrm{n} .36$, and the holding in TV 9 have been read together as establishing a policy in favor of increasing the number of minority-owned stations, regardless of the effect on service offered. See 52 TEx. L. REv. 806, 813 (1974).

in Cf. RKO General, Inc., 44 F.C.C.2d 149, 194-95, 16 P \& F Radio Reg. 2D 1181, 123435 (Hearing Examiner 1969) (initial decision). Since licenses are issued so that all licenses in a state expire on the same day, a challenger has its pick of targets. 
carefully before risking up to $\$ 250,000$ on a challenge, ${ }^{168}$ the Commission could probably allow the market to handle this problem itself.

The second problem is a variant of that already discussed in the context of the comparative renewal procedure generally. There is a substantial possibility that this policy could be abused by sham applications in which minority members file an application on behalf of silent white backers. Here again, the Commission may wish to use conditional licenses and to scrutinize with extra care the renewal applications of successful challengers. On the other hand, the Commission must be careful not to inhibit all minority applications through protective restrictions.

b. Specialized Format. The problem of allocating frequencies for specialized programming has indirectly arisen in the recent "format change" cases, in which the Court of Appeals has required the Commission to hold hearings before allowing a licensee that has specialized in a particular kind of programming to transfer its license to one that plans to use a mass-appeal format. In the leading case of Citizens Committee to Preserve the Voice of the Arts in Atlanta v. FCC, ${ }^{169}$ the court observed:

$[\Pi \mathrm{t}$ is surely in the public interest . . . for all major aspects of contemporary culture to be accomodated by the commonly owned public resources whenever that is technically and economically feasible. ${ }^{170}$

Thus, as with minority access, the Court of Appeals has a recognized public interest in specialized programming that the Commission could employ as it employs the $307(\mathrm{~b})$ issue.

The major difficulty with using special format considerations as a preliminary issue is that it would require the Commission once again to allocate licenses on the basis of predictions of future service. Whereas increasing the number of minority-owned stations is desirable per se on policy grounds, inclusion of the specialized for-

16* Hearings, supra note 66 , at 38 .

169436 F.2d 263 (D.C. Cir. 1973). See also Citizens Committee to Save WEFM v. FCC, 506 F.2d 246 (D.C. Cir. 1974); Citizens Committee to Keep Progressive Rock v. FCC, 478 F.2d 926 (D.C. Cir. 1973); Lakewood Broadcasting Service, Inc. v. FCC, 478 F.2d 919 (D.C. Cir. 1973); Hartford Communication Committee v. FCC, 467 F.2d 408 (D.C. Cir. 1972). See generally Note, Judicial Review of FCC Program Diversity Regulations, 75 CoLUM. L. Rev. 401, 419-34 (1975).

170436 F.2d at 269. In passing on a format change application, the Commission must consider the size of the audience for the specialized programming, the station's economic need to change formats, and the existence of other sources of the programming. Id. at 269-72. 
mat issue would require the Commission to predict whether an applicant really intends to implement its programming proposals. ${ }^{171}$ Consequently, the specialized format issue should not be applied in comparative renewal cases except where an applicant can clearly demonstrate, on the basis of a past record of operating such facilities, a substantial likelihood that it will in fact implement its proposals. Continuation of its license should be conditional on its continuing its special format.

\section{The Commission's Authority to Adopt the Proposed Procedure}

Whether adoption of the proposed procedure is within the authority of the Commission essentially involves two questions: whether a procedure under which a challenger's application can be denied solely on the basis of the incumbent's record through the stability issue deprives the challenger of its right to a hearing under Ashbacker and Citizens, and whether disposition of a comparative hearing solely on the basis of the structural issues outlined above violates Johnston Broadcasting.

As noted above, ${ }^{172}$ the Commission has been permitted under Storer and its progeny to deny the application of an unqualified applicant without a hearing. The Citizens court dismissed Storer on the grounds that the 1970 Policy Statement did not involve qualification standards of the Commission. ${ }^{173}$ The use of the term "qualifications" in this context, however, is question-begging. Storer's application was not denied without a hearing because Storer was incapable of operating a station properly, ${ }^{174}$ but because, as a matter of policy, the Commission had determined that the frequency should be occupied instead by a broadcaster with fewer media interests. The Commission was upheld in this practice even though a competing application had not yet been filed and thus the frequency might eventually be allocated to an inferior broadcaster. The Citizens court was thus incorrect in dismissing Storer as wholly inapplicable and should have instead focused on the reasonableness

ii The Commission has refused to adopt special format rules in its allocation policies, stating: "As we have consistently held, program formats are by their nature transitory, and we have accordingly refused to consider them in designing and implementing our allocation system . . . " Report and Order, in re Amendment of Part 73 of the Commission's Rules Regarding AM Station Assignment, 54 F.C.C.2d 1, 22, 34 P \& F RADlo REG. 2D 603, 626 (1975); see text and notes at notes 33-36 supra.

172 See text and notes at notes 132-36 supra.

1i3 447 F.2d at 1212 n.34.

ii 351 U.S. at 201. 


\section{of the Commission's classification. ${ }^{175}$}

If the Court of Appeals were to scrutinize this proposal under Storer, it could distinguish Citizens. It is easy to conclude that an otherwise qualified challenger should not be considered unqualified and denied a hearing because the incumbent has an average operating record: in this case it must be assumed that the applicants will render roughly equivalent service and thus the public interest calls for allocating the license on the basis of other policies properly determined in a comparative hearing. It is another thing, however, to make this argument when the incumbent has an outstanding record: in this case there is a strong public interest in continuing the outstanding service that, like the 307 (b) policy of providing an unserviced area with some service, could override the challenger's individual interest. Because the Commission is unable to predict whether an untested challenger will render equally superior service, the public interest would call for retaining the incumbent. The proposed revamping of the comparative renewal hearing could, therefore, pass muster after Citizens as long as the Commission can effectively separate outstanding incumbents from average ones and apply the policy only to the former. ${ }^{176}$

Johnston Broadcasting also would not bar implementation of the proposed procedure. As noted before, in Allentown Broadcasting the Court held that the Commission need not compare all relevant: differences between two applicants when disposing of a comparative hearing on $307(\mathrm{~b})$ grounds. ${ }^{177}$ Although the $307(\mathrm{~b})$ issue rests on a specific, clear statutory mandate, the Commission apparently has authority to develop special criteria to apply in comparative renewal cases. The Communications Act originally required the Commission to judge renewal applications under the same standards it used in judging original applications. ${ }^{178}$ In 1952, the Act was amended to provide simply that renewals were to be governed by the public

175 In Kessler v. FCC, 326 F.2d 673, $687-88$ (D.C. Cir. 1963), the court interpreted Storer to permit the Commission to impose a freeze on granting new AM licenses, but held that it must hold a comparative hearing between two mutually exclusive applicants, one filed just before the effective date of the freeze and one just after. The freeze policy could not be used to prefer one applicant over another where the only difference between the applicants-the time their applications were filed-bore no relationship to the public policy behind the freeze: restricting the number of AM stations.

${ }^{176}$ If the proposed stability issue can be upheld, there should be little problem in upholding the access issues. The stability issue is much closer to the invalidated 1970 Policy Statement. See text and notes at notes 86-102 supra.

in See text at notes 140-43 supra.

${ }^{17 x}$ Ch. 652, § 307(d), 48 Stat. 1084 (1934). 
interest, convenience and necessity, ${ }^{179}$ thus suggesting that Congress intended to free the Commission to develop special standards to govern comparative renewal situations. ${ }^{180}$

In any event, the concept of "relevant differences between the applicants" has been greatly altered since Johnston Broadcasting. Today, the Commission, with the Court of Appeals' acquiescence, generally considers the applicants' relative degree of conformity to its model of an ideal licensee to be the sole relevant difference. Only occasionally does the Commission consider differences in proposed programming, because they afford no basis for a rational choice. If the Commission considers all the noncomparative factors in relation to the applicants, there seems to be no reason why it cannot similarly refuse to consider the standard comparative criteria if the allocative choice should be made on the basis of other policies. ${ }^{181}$ Indeed, although the Citizens court invoked Johnston, it clearly contemplated that renewal hearings would be resolved according to standards similar to those outlined in the proposed procedure. ${ }^{182}$ Thus neither Ashbacker, Johnston nor Citizens bars implementation of the proposed procedure.

\section{CONCLUSION}

The FCC has thus far been unable to formulate standards for rational license allocation in comparative renewal situations. Having recognized that the comparative criteria of the 1965 Policy Statement-which are based on policies concerning the structure of the broadcast industry rather than attempts to predict which applicant will provide the best service-do not furnish reliable guides in cases where one applicant has been operating on the frequency in question, the Commission must now develop a mechanism that will enable it, when appropriate, to allocate licenses on the basis of noncomparative policies without violating either incumbents' or challengers' statutorily guaranteed right to a meaningful hearing. In treading this fine line, the Commission has a judicially-approved model to follow. Under Storer the Commission need not grant a 714.

sig 47 U.S.C. $\$ 307$ (d) (1970), as amended by Act of July 16, 1952, ch. 879, § 5, 66 Stat.

${ }^{1 \times 0}$ See Geller, The Comparative Renewal Process in Television: Problems and Suggested Solutions, 61 VA. I. Rev. 471, 472-73 (1975). But see Citizens Communication Center v. FCC, 447 F.2d 1201, 1206 n.13 (D.C. Cir. 1971).

IxI For an argument that a similar proposed system would not be barred by Johnston, see Anthony, supra note 23 , at 75-84.

1x2 447 F.2d at $1213 \mathrm{nn} .35 \& 36$; see text at notes 86-102 supra. 
hearing to a demonstrably unqualified applicant and under Allentown Broadcasting it may define qualification on the basis of the public's need for different types of broadcast services, as it does in resolving the $307(\mathrm{~b})$ issue. Using these principles as a model, the Commission could embody its concern with promoting such policies as stability in the industry and minority group access to the airwaves in qualification standards that could be applied in comparative renewal situations. Such an approach would have numerous advantages: the Commission could base its decisions on objective, noncomparative determinations where appropriate; an expectation of renewal for a superior record could be used to encourage high quality programming without shielding mediocre licensees from competition; the basis for comparative renewal decisions could be made clear and explicit; and, in cases where the non-comparative criteria are not dispositive, the Commission would have no reason not to apply the 1965 Policy Statement criteria and thus could implement its diversification-integration structural policies. Such a mechanism, if formulated through rulemaking procedures and designed carefully to avoid giving any party an advantage not based on a defined public interest, would not offend the right to a hearing guaranteed challengers as well as incumbents by Ashbacker, Johnston Broadcasting, and Citizens. ${ }^{183}$

Durward J. Gehring

${ }^{1 \times 3}$ The Citizens court itself stated: "The court recognizes that the public itself will suffer if incumbent licensees cannot reasonably expect renewal when they have rendered superior service." 447 F.2d at 1213 n.35. 